OPEN ACCESS

Edited by:

Davide Tiranti,

Agenzia Regionale per la Protezione

Ambientale (ARPA), Italy

Reviewed by:

Nadia Solovieva,

University College London,

United Kingdom

Xiaozhong Huang,

Lanzhou University, China

${ }^{*}$ Correspondence:

S. Wetterich

sebastian.wetterich@awi.de

Specialty section:

This article was submitted to

Quaternary Science, Geomorphology

and Paleoenvironment,

a section of the journal

Frontiers in Earth Science

Received: 16 March 2021

Accepted: 03 June 2021

Published: 18 June 2021

Citation:

Wetterich S, Rudaya N, Nazarova L,

Syrykh L, Pavlova M, Palagushkina O,

Kizyakov A, Wolter J, Kuznetsova T, Aksenov A, Stoof-Leichsenring $K R$,

Schirrmeister $L$ and Fritz $M$ (2021)

Paleo-Ecology of the Yedoma Ice

Complex on Sobo-Sise Island

(EasternLena Delta, Siberian Arctic).

Front. Earth Sci. 9:681511.

doi: 10.3389/feart.2021.681511

\section{Paleo-Ecology of the Yedoma Ice Complex on Sobo-Sise Island (EasternLena Delta, Siberian Arctic)}

\author{
S. Wetterich ${ }^{1 *}$, N. Rudaya ${ }^{2,3}$, L. Nazarova ${ }^{1,4,5}$, L. Syrykh ${ }^{6}$, M. Pavlova ${ }^{7}$, O. Palagushkina ${ }^{5}$, \\ A. Kizyakov $^{8}$, J. Wolter ${ }^{1,9}$, T. Kuznetsova ${ }^{10,5}$, A. Aksenov ${ }^{11,12}$, K. R. Stoof-Leichsenring ${ }^{1}$, \\ L. Schirrmeister ${ }^{1}$ and M. Fritz ${ }^{1}$
}

\begin{abstract}
${ }^{1}$ Alfred Wegener Institute Helmholtz Centre for Polar and Marine Research, Potsdam, Germany, ${ }^{2}$ PaleoData Lab, Institute of Archaeology and Ethnography SB RAS, Novosibirsk, Russia, ${ }^{3}$ Biological Institute, Tomsk State University, Tomsk, Russia, ${ }^{4}$ Institute of Geosciences, University of Potsdam, Potsdam, Germany, ${ }^{5}$ Research Laboratory of Palaeoclimatology, Palaeoecology, Palaeomagnetism, Kazan (Volga Region) Federal University, Kazan, Russia, ${ }^{6}$ Faculty of Geography, Herzen State Pedagogical University of Russia, St. Petersburg, Russia, ${ }^{7}$ Melnikov Permafrost Institute Siberian Branch of the Russian Academy of Science, Yakutsk, Russia, ${ }^{8}$ Department of Cryolithology and Glaciology, Faculty of Geography, Lomonosov Moscow State University, Moscow, Russia, ${ }^{9}$ Institute of Biochemistry and Biology, University of Potsdam, Potsdam, Germany, ${ }^{10}$ Department of Paleontology, Faculty of Geology, Lomonosov Moscow State University, Moscow, Russia, ${ }^{11}$ Department of Polar Geography, Arctic and Antarctic Research Institute, St. Petersburg, Russia, ${ }^{12}$ Institute of Earth Sciences, Petersburg State University, St. Petersburg, Russia
\end{abstract}

Late Pleistocene permafrost of the Yedoma type constitutes a valuable paleoenvironmental archive due to the presence of numerous and well-preserved floral and faunal fossils. The study of the fossil Yedoma inventory allows for qualitative and quantitative reconstructions of past ecosystem and climate conditions and variations over time. Here, we present the results of combined paleo-proxy studies including pollen, chironomid, diatom and mammal fossil analyses from a prominent Yedoma cliff on SoboSise Island in the eastern Lena Delta, NE Siberia to complement previous and ongoing paleo-ecological research in western Beringia. The Yedoma Ice Complex (IC) cliff on SoboSise Island (up to $28 \mathrm{~m}$ high, $1.7 \mathrm{~km}$ long) was continuously sampled at $0.5 \mathrm{~m}$ resolution. The entire sequence covers the last about 52 cal kyr BP, but is not continuous as it shows substantial hiatuses at 36-29 cal kyr BP, at 20-17 cal kyr BP and at 15-7 cal kyr BP. The Marine Isotope Stage (MIS) 3 Yedoma IC (52-28 cal kyr BP) pollen spectra show typical features of tundra-steppe vegetation. Green algae remains indicate freshwater conditions. The chironomid assemblages vary considerably in abundance and diversity. Chironomidbased $\mathrm{T}_{\text {July }}$ reconstructions during MIS 3 reveal warmer-than-today $\mathrm{T}_{\text {July }}$ at about $51 \mathrm{cal} \mathrm{kyr} \mathrm{BP,} \mathrm{46-44} \mathrm{and} 41 \mathrm{cal} \mathrm{kyr} \mathrm{BP.} \mathrm{The} \mathrm{MIS} 2$ Yedoma IC (28-15 cal kyr BP) pollen spectra represent tundra-steppe vegetation as during MIS 3, but higher abundance of Artemisia and lower abundances of algae remains indicate drier summer conditions. The chironomid records are poor. The MIS 1 (7-0 cal kyr BP) pollen spectra indicate shrub-tundra vegetation. The chironomid fauna is sparse and not diverse. The chironomid-based $T_{\text {July }}$ reconstruction supports similar-as-today temperatures at 6.4-4.4 cal kyr BP. Diatoms were recorded only after about 6.4 cal kyr BP. The SoboSise Yedoma record preserves traces of the West Beringian tundra-steppe that maintained the Mammoth fauna including rare evidence for woolly rhinoceros' 
presence. Chironomid-based $\mathrm{T}_{\text {July }}$ reconstructions complement previous plantmacrofossil based $T_{\text {July }}$ of regional MIS 3 records. Our study from the eastern Lena Delta fits into and extends previous paleo-ecological Yedoma studies to characterize Beringian paleo-environments in the Laptev Sea coastal region.

Keywords: permafrost, Yedoma, paleo-ecology, pollen, chironomids, Mammoth fauna, late Pleistocene, Beringia

\section{INTRODUCTION}

Late Pleistocene permafrost of the Yedoma type is a prominent and widespread permafrost feature that formed during sea-level lowstands on vast areas of the unglaciated Beringian lowlands and on the nowadays flooded East Siberian shelf between the Laurentide to the east and the Scandinavian ice sheets to the west during marine isotope stages (MIS) 4 to 2 (Hopkins, 1959). Ice Complex (IC) permafrost aggradation took place by evolving ice-wedge polygons forming the so-called Yedoma IC (Katasonov, 1954/2009) of up to $50 \mathrm{~m}$ thick sequences. In West Beringia, the main area of potential Yedoma IC distribution includes the now submerged East Siberian shelf and Arctic coastal lowlands from Taymyr Peninsula to Chukotka (Grosse et al., 2013), although it is also described from interior regions of Central Yakutia (Soloviev, 1959) and the Yana Upland (Kunitsky et al., 2013; Opel et al., 2019). In East Beringia, muck deposits comparable in genesis to those of Siberian Yedoma IC occur at the Arctic Foothills, on Seward Peninsula, in interior Alaska and in the Yukon Territory (Péwé, 1955; Kanevskiy et al., 2011; Schirrmeister et al., 2016).

Large syngenetic ice wedges, ice-oversaturated fine-grained deposits and a considerable organic content characterize Yedoma IC deposits (Schirrmeister et al., 2013). The organic component of Yedoma IC preserves floral and faunal fossils, and thus evidence of late Pleistocene environmental and climatic conditions of Beringia and their variations over time (e.g., Sher et al., 2005). The Yedoma permafrost archive has been widely used to infer rather qualitative than quantitative paleoenvironmental reconstructions by applying numerous fossil records such as those from Mammoth fauna bones (e.g., Kuznetsova et al., 2019), insect remains (e.g., Sher et al., 2005), plant macro-remains (e.g., Kienast et al., 2005), pollen (e.g., Andreev et al., 2011), testate amoebae (e.g., Bobrov et al., 2004) or ostracods (Wetterich et al., 2005). Generally, the combination of several fossil proxy records from a certain permafrost sequence largely enhances its significance for paleo-ecological interpretations (e.g., Kienast et al., 2011; Wetterich et al., 2018). In this context, the present study combines a pollen-based paleo-vegetation reconstruction with lacustrine chironomid and diatom analyses. While pollen analysis provides detailed insights into vegetation dynamics over time with high comparability to other regional pollen records (Andreev et al., 2011), lacustrine fossil proxies highlight onsite freshwater conditions by habitat preferences of certain species, and species diversity (Palagushkina et al., 2012; Hoff et al., 2015; Palagushkina et al., 2017; Biskaborn et al., 2019). If specimen counts per sample are sufficiently high, numerical reconstructions of certain ecological parameters are deducible such as mean air temperature of the warmest month $\left(\mathrm{T}_{\text {July }}\right)$, water depth, ion content and pH (Nazarova et al., 2013; Nazarova et al., 2017a; Pestryakova et al., 2018).

The study area on Sobo-Sise Island in the eastern Lena Delta fits into and extends previous paleo-ecological Yedoma studies in the Laptev Sea coastal region including the Lena Delta and Bykovsky Peninsula (Schirrmeister et al., 2002a; Schirrmeister et al., 2003; Bobrov et al., 2004; Kienast et al., 2005; Sher et al., 2005; Wetterich et al., 2005; Wetterich et al., 2008a; Wetterich et al., 2011; Schirrmeister et al., 2011a; Schirrmeister et al., 2011b; Wetterich et al., 2014; Schirrmeister et al., 2017; Khazin et al., 2019; Kuznetsova et al., 2019; Wetterich et al., 2019a), which examined floral and faunal fossils. These studies characterized the West Beringian environments generally as tundra-steppe covering a considerable patchiness of different habitats that created a landscape mosaic of dry uplands and slopes, wetlands, floodplains and shallow waters of low-center polygon tundra as especially well seen in insect and plant macrofossil data (Kienast et al., 2005; Sher et al., 2005; Wetterich et al., 2008a). However, aquatic conditions in West Beringia during MIS 3-2 are rather poorly constrained yet and are mainly based on findings of: 1) green algae Botryococcus and Pediastrum remains in palynological samples, 2) submerged and water plant macro-fossils, and 3) ostracod valves in Yedoma IC deposits. Other aquatic fossils such as from branchiopods, cladocerans and chironomids have only little been studied yet in Yedoma IC deposits (Neretina et al., 2020; Rogers et al., 2021). Numerical reconstructions of paleo-climate parameters such as summer air temperature and annual precipitation in West Beringia are scarce (Andreev et al., 2011) or poorly developed in case of ice-wedge stable water isotopic composition reflecting winter climate (Opel et al., 2018; Wetterich et al., 2021). Pitulko et al. (2017) present $\mathrm{T}_{\text {July }}$ and precipitation reconstructions from 34 to $10 \mathrm{kyr} B P$ for the western part of the Yana-Indigirka Lowland (east of our study region), while from the Bykovsky Yedoma archive only two points in time, at around 48 and $35 \mathrm{kyr} \mathrm{BP}$, provide estimated $\mathrm{T}_{\text {July }}$ values based on plant macrofossils (Kienast et al., 2005). Further quantitative paleo-proxy reconstruction data are lacking for the Laptev Sea coastal region. Thus, additional information is mandatory to better constrain the West Beringian climate and environment through stadial-interstadial as well as glacialinterglacial transitions.

In addition to a recent study of the cryostratigraphic inventory of the Sobo-Sise Yedoma cliff (Wetterich et al., 2020) and to previous paleo-environmental Yedoma research in the Laptev Sea coastal region, the present study aims

1) To provide detailed pollen-based reconstructions of paleovegetation in combination with occasional bone findings of the Mammoth fauna; 


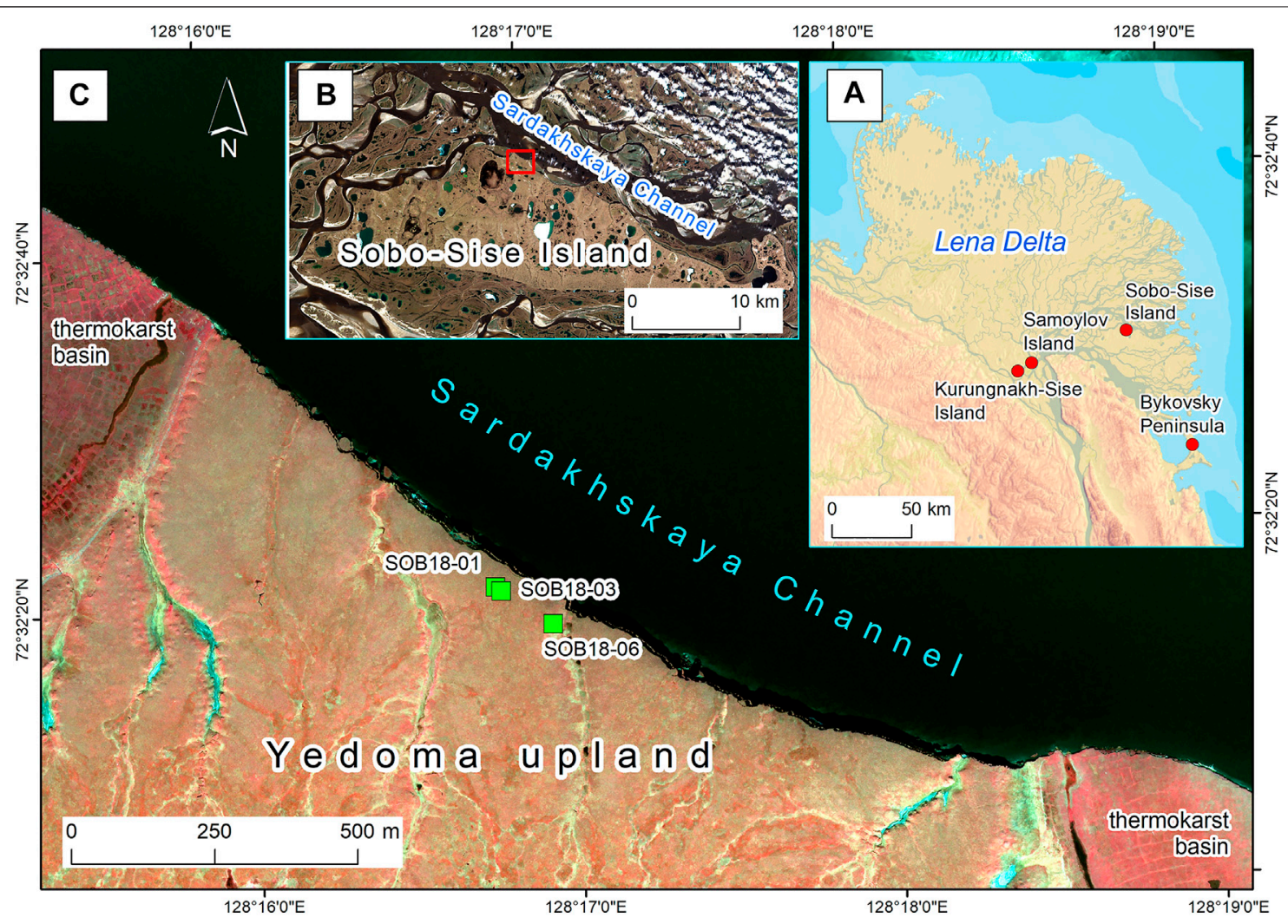

FIGURE 1 | Study area in north-eastern Siberia showing (A) the Lena Delta with key locations, (B) Sobo-Sise Island (image based on Sentinel-2A scene, June 27, 2018) and (C) the Sobo-Sise Yedoma cliff facing the Sardakhskaya Channel (image based on GeoEye-1 scene, July 08, 2014) with positions of the sampled sediment profiles SOB18-01, SOB18-03 and SOB18-06. Panel (A) is based on the semitransparent layer of the ESRI ArcGIS Living Atlas of the World (World Topo Base, 2021) with underlying bathymetry of (IBCAO grid, 2021).

2) To reconstruct past freshwater lacustrine conditions such as water depth, salinity, $\mathrm{pH}$, and $\mathrm{T}_{\text {July }}$ air temperatures based on chironomid and diatom fossils;

3) To disentangle regional paleo-environmental dynamics in West Beringia by combining the present record with previous research results and interpretations.

\section{STUDY SITE AND PREVIOUS RESEARCH}

\section{Sobo-Sise Island in the Eastern Lena Delta}

The Lena Delta is the largest delta in the Arctic and occupies about $32,000 \mathrm{~km}^{2}$ (Are and Reimnitz, 2000). It is divided by six major channels (Fedorova et al., 2015) of which the Sardakhskaya Channel drains the eastern part of the delta (Figure 1). Here, on Sobo-Sise Island at the Sardakhskaya Channel Yedoma uplands occupy about $19 \%$ of the land surface while most of the island is characterized by permafrost degradation features such thermokarst basins and thermoerosional valleys of Holocene age (Fuchs et al., 2018). A prominent Yedoma IC remnant at the north-eastern shore of Sobo-Sise Island builds an up to about $28 \mathrm{~m}$ high almost vertical cliff $\left(72^{\circ} 32^{\prime} \mathrm{N}, 128^{\circ} 17^{\prime}\right.$ E) stretching about $1,700 \mathrm{~m}$ along the shore (Figure 1).

The modern meteorological conditions in the Lena Delta are monitored on Samoylov Island where a mean annual air temperature of $-12.3^{\circ} \mathrm{C}$, mean July air temperature of $9.5^{\circ} \mathrm{C}$ and mean February air temperature of $-32.7^{\circ} \mathrm{C}$ are recorded for the last two decades (1998-2017; Boike et al., 2019), while the mean annual rainfall amounts to $169 \mathrm{~mm}$ and the mean annual winter snow cover to $0.3 \mathrm{~m}$ (2002-2017; Boike et al., 2019).

On Sobo-Sise Island, dwarf shrub-moss-tussock tundra plant communities inhabit the structured land surface of Yedoma uplands, pingos, floodplains, and thermokarst basins. Species of the Salix, Dryas, Saxifraga, Polygonum, Carex, Poa, Trisetum, Equisetum, and Luzula genera, and unspecified mosses and lichens are common (Raschke and Savelieva, 2017).

\section{Evolution of the Sobo-Sise Yedoma Sequence}

The Sobo-Sise Yedoma cliff attracts scientific attention due to both, the exceptionally high and vertically exposed permafrost archive spanning MIS 3-1 (Wetterich et al., 2020) and the ongoing rapid thermo-erosion releasing substantial amounts of organic matter into the Lena River (Fuchs et al., 2020).

The geochronological record of the Sobo-Sise Yedoma spans the last 52 cal kyr BP based on radiocarbon dating and age-height modeling (Figure 2; Wetterich et al., 2020). The permafrost sequence differentiates into three cryostratigraphic units that 

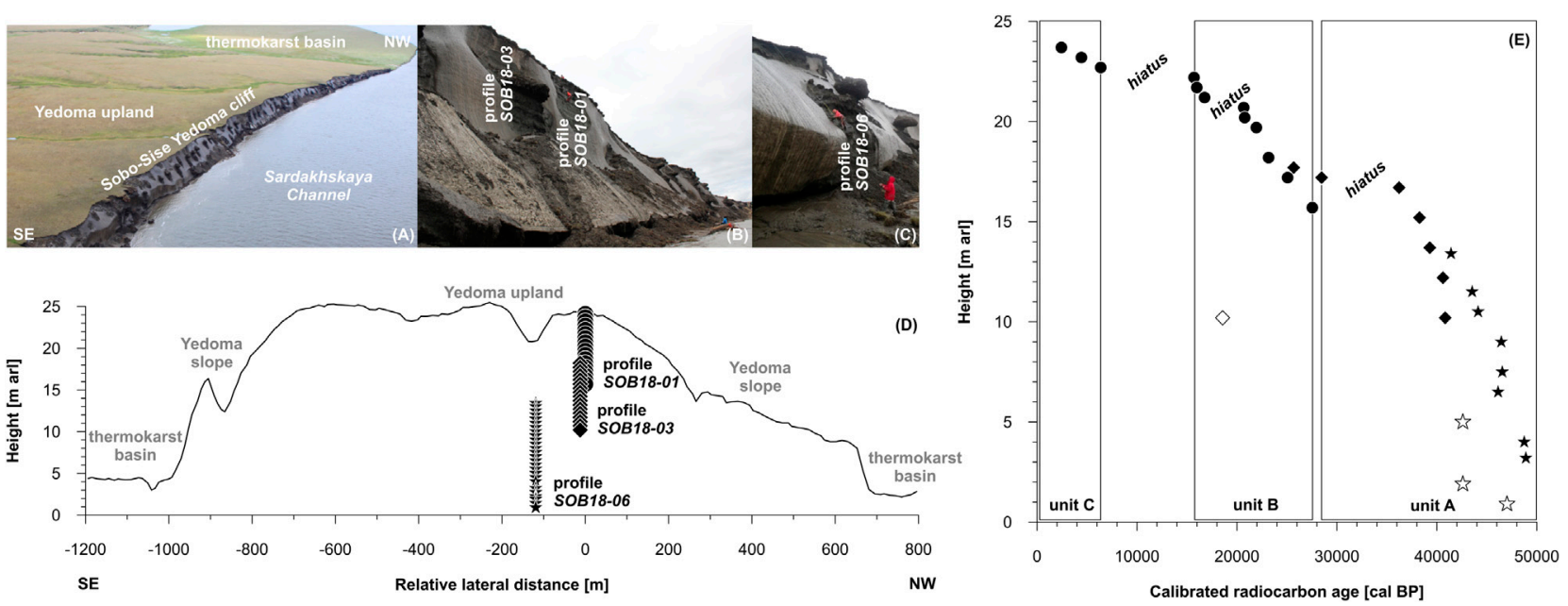

FIGURE 2 | Overview of the sampled profiles at Sobo-Sise showing (A) the Yedoma cliff, (B) profiles SOB18-01 and SOB18-03, (C) profile SOB18-06, (D) sampling scheme across the Yedoma cliff and (E) age-height relation of the exposure in meter above river level ( $\mathrm{m}$ arl) and calibrated radiocarbon ages (redrawn from Wetterich et al., 2020). Note the sampling overlap of the profiles SOB18-01 (circles), SOB18-03 (diamonds) and SOB18-06 (stars) and their alignment to cryostratigraphic units A, B and C. The hollow symbols indicate ages of re-deposited material or infinite radiocarbon ages.

are MIS 3 Yedoma IC (unit A; 52-28 cal kyr BP), MIS 2 Yedoma IC (unit B; 28-15 cal kyr BP) and MIS 1 Holocene cover (unit C; 7-0 cal kyr BP). The cryostratigraphic sequence of the Sobo-Sise Yedoma cliff is not continuous, but has chronological gaps (hiatuses) at $36-29 \mathrm{cal} \mathrm{kyr} \mathrm{BP,} \mathrm{at} \mathrm{20-17} \mathrm{cal} \mathrm{kyr} \mathrm{BP} \mathrm{and} \mathrm{at}$ 15-7 cal kyr BP (Figure 2).

The chronological gaps provide evidence of past changes in climatic conditions as well as in sediment deposition and erosion regimes. Similar observations have been made on adjacent Yedoma IC sites on Bykovsky Peninsula and Kurungnakh-Sise Island (Wetterich et al., 2020). The two older gaps during MIS 3 and MIS 2 are likely related to repeated changes in the regional hydrological systems due to outburst floods of glacial Lake Vitim along the Lena Valley into the Arctic Ocean as proposed by Margold et al. (2018), while the MIS 2-1 gap corresponds to deglacial permafrost thaw (thermokarst) that took place Arcticwide at the late Pleistocene-Holocene transition.

The Sobo-Sise Yedoma cliff rapidly erodes with a mean annual shoreline retreat rate of up to $9.1 \mathrm{~m} \mathrm{yr}^{-1}$ over the last decades (1965-2018; Fuchs et al., 2020). Surface elevation changes due to thaw subsidence on Yedoma uplands range between $-2 \mathrm{~cm} \mathrm{yr}^{-1}$ (based on Sentinel-1 InSAR, 2017, for the entire Sobo-Sise Island; Chen et al., 2018) and $-3.4 \mathrm{~cm} \mathrm{yr}^{-1}$ (based on on-site rLiDAR at the studied Yedoma cliff, Günther et al., 2018). Thus, the SoboSise Yedoma IC remnant of today is characterized by substantial and rapid permafrost degradation (Fuchs et al., 2020).

\section{METHODS}

\section{Fieldwork and Dating}

Three vertical sediment profiles were sampled on rope at accessible positions of the Yedoma cliff to cover the entire exposed permafrost inventory (Wetterich et al., 2019b;
Figure 2). The frozen samples were obtained using a hammer and axe at $0.5-\mathrm{m}$ resolution. Vertical overlaps of the three profiles guaranteed complete coverage of the exposure (Figure 2D).

The sampling resulted in a total of 61 sediment samples. Upon return to the labs, samples were freeze-dried (Zirbus Subliminator 3-4-5) and split into subsamples for several analyses. Accelerator mass spectrometry (AMS) radiocarbon dating was applied to identified organic macro-remains in 31 sediment samples totaling in 32 radiocarbon dates (Wetterich et al., 2020), which were calibrated using the IntCal13 calibration dataset (Reimer et al., 2013). Ages are given as calibrated years before present (cal yr BP) or calibrated thousand years before present (cal kyr BP). Paleoecological analyses were conducted on a sample set of 33 samples from the profiles SOB18-01 $(n=14)$ SOB18-03 $(n=7)$ and SOB18-06 $(n=12)$ covering the entire sequences at resolution of less than $1 \mathrm{~m}$.

\section{Pollen Analysis}

The pollen samples (2-6 g of dry sediment) were prepared using standard procedures including treatment with $10 \% \mathrm{HCl}$ and $10 \%$ $\mathrm{KOH}$, sieving $(250 \mathrm{~mm})$, treatment with $45 \% \mathrm{HF}$, acetolysis, and mounting in glycerin (cf. Fægri and Iversen, 1989). One Lycopodium spore tablet was added to each sample to calculate total pollen and spore concentrations (cf. Stockmarr, 1971). Pollen and spore residues mounted in water-free glycerin were analyzed under a Zeiss AxioImager D2 light microscope at 400 magnification. The identification of pollen and spores was performed using a reference pollen collection and pollen atlases (e.g., Beug, 2004). Non-pollen palynomorphs (NPPs) were identified using descriptions, sketches, and photographs published by van Geel (2001). The percentages of all taxa were calculated based on setting the total of all pollen and spore taxa equal to $100 \%$. The results of pollen analysis are displayed in the pollen diagram produced with the Tilia/TiliaGraph software. The 
TABLE 1 | List of bone findings of the late Pleistocene Mammoth fauna on Sobo-Sise Island in the eastern Lena Delta.

\begin{tabular}{|c|c|c|c|c|c|c|c|}
\hline Order & Family & Species & Total & $\begin{array}{c}\text { ZIN RAS St. } \\
\text { Petersburg } \\
\text { (1927) }\end{array}$ & $\begin{array}{c}\text { Expedition } \\
\text { Lena Delta } \\
\text { (1998) }\end{array}$ & $\begin{array}{l}\text { Lena Delta } \\
\text { Reserve } \\
\text { Tiksi (1990, } \\
\text { 2000) }\end{array}$ & $\begin{array}{c}\text { Lena Delta } \\
\text { Reserve } \\
\text { Tiksi (2018) }\end{array}$ \\
\hline Proboscidea & Elephantidae & $\begin{array}{l}\text { Mammuthus primigenius } \\
\text { (BLUMENBACH, 1799) }\end{array}$ & 30 & 11 & 5 & 8 & 6 \\
\hline \multirow[t]{2}{*}{ Artiodactyla } & Bovidae & Bison priscus (BOJANUS, 1827) & 7 & 6 & & & 1 \\
\hline & Cervidae & Rangifer tarandus L., 1758 & 3 & & & & 3 \\
\hline \multirow[t]{3}{*}{ Perissodactyla } & Equidae & Equus ex eg. caballus L., 1758 & 4 & 1 & 1 & 2 & \\
\hline & $\begin{array}{l}\text { Rhino- } \\
\text { cerotidae }\end{array}$ & $\begin{array}{l}\text { Coelodonta antiquitatis } \\
\text { (BLUMENBACH, 1799) }\end{array}$ & 1 & & & & 1 \\
\hline & & Total & 45 & 18 & 6 & 10 & 11 \\
\hline
\end{tabular}

TABLE 2 | Radiocarbon ages of Mammuthus primigenius bone fragments from Sobo-Sise Island (Eastern Lena Delta) calibrated using CALIB REV8.2 (Reimer et al., 2020). Results are rounded to the nearest $10 \mathrm{yr}$ for samples with standard deviation in the radiocarbon age greater than $50 \mathrm{yr}$.

\begin{tabular}{|c|c|c|c|c|c|c|c|c|}
\hline Sample ID & Lab ID & $\begin{array}{c}{ }^{14} \mathrm{C} \text { date } \\
\text { (yr BP) }\end{array}$ & $\begin{array}{l}\text { Calibrated } \\
\text { age range } \\
2 \sigma \text { (cal } \\
\text { yr BP) }\end{array}$ & $\begin{array}{c}\text { Calibrated } \\
\text { median } \\
\text { age (cal } \\
\text { yr BP) }\end{array}$ & $\begin{array}{l}\text { Skeleton } \\
\text { element }\end{array}$ & Locality & $\begin{array}{c}\text { Year } \\
\text { of } \\
\text { sampling }\end{array}$ & References \\
\hline $\begin{array}{l}\text { SOB18- } \\
\text { bone-02 }\end{array}$ & AWI2749.1.2 & $13,668 \pm 57$ & $16,310-16,750$ & 16,520 & Tusk, fragment & Shore & 2018 & $\begin{array}{l}\text { Wetterich et al. } \\
(2020)\end{array}$ \\
\hline GIN-4115 & GIN-4115 & $14,340 \pm 120$ & $17,100-17,860$ & 17,490 & Tusk, fragment & $\begin{array}{l}\text { "Bone horizon" at } \\
13-15 \mathrm{~m} \text { arl }\end{array}$ & 1984 & Grigoriev (1988) \\
\hline LDR- O299 & KIA-32839 & $17,070 \pm 70$ & $20,460-20,830$ & 20,630 & Forearm & & 1990 & This paper \\
\hline MKh-O621 & GIN-10235 & $19,200 \pm 220$ & $22,650-23,760$ & 23,180 & Rib, fragment & Shore & 1998 & Sher et al. (2005) \\
\hline IM-835 & IM-835 & $24,400 \pm 650$ & $27,410-29,950$ & 28,620 & Bone & & & This paper \\
\hline MKh-O624 & $\begin{array}{l}\text { GIN-13929 (GrA- } \\
46013)\end{array}$ & $>45,000$ & Not calibrated & Not calibrated & $\begin{array}{l}\text { Vertebra, } \\
\text { fragment }\end{array}$ & Shore & 1998 & This paper \\
\hline
\end{tabular}

visual definition of the pollen record is supported by cluster analysis in CONISS (Grimm, 2004).

\section{Mammal Bone Analysis}

Mammal bone findings in fresh slump debris at the cliff foot were collected in 2018 during fieldwork (Table 1), later on identified, and are currently stored at the Lena Delta Reserve (LDR), Tiksi, Russia. Archive data of late Pleistocene mammal bones from Sobo-Sise Island (Table 1) are available from sampling in 1927 (Zoological Institute Russian Academy of Science - ZIN RAS, Sankt-Petersburg, Russia), in 1990 and 2000 (LDR, Tiksi, Russia) and in 1998 (Collection of the Russian-German "Lena Delta" Expedition, Moscow, Russia), Radiocarbon dates are available for five specimens of these archive collections (Table 2).

\section{Chironomid Analysis}

The treatment of sediment samples for chironomid analysis followed standard techniques described in Brooks et al. (2007). Subsamples of wet sediments were deflocculated in $10 \% \mathrm{KOH}$, heated to $70^{\circ} \mathrm{C}$ for $10 \mathrm{~min}$ by adding boiling water and left for another $20 \mathrm{~min}$. The sediment was then passed through stacked 225 and $90 \mu \mathrm{m}$ sieves. Chironomid larval head capsules (HC) were picked out of a grooved Bogorov sorting tray under a stereomicroscope at 25-40x magnification and were mounted in Hydromatrix two at a time, ventral side up, under a $6 \mathrm{~mm}$ diameter cover slip. Chironomids were identified to the highest possible taxonomic resolution following Wiederholm (1983) and Brooks et al. (2007). Information on ecological preferences of identified chironomid taxa was taken from Brooks et al. (2007), Moller Pillot (2009), Moller Pillot (2013) and Nazarova et al. (2008); Nazarova et al. (2011); Nazarova et al. (2015); Nazarova et al. (2017b).

Mean July air temperatures $\left(\mathrm{T}_{\text {July }}\right)$ were inferred by using a North Russian (NR) chironomid-based temperature inference model (WA-PLS, 2 component; $\mathrm{r}^{2}$ boot $=0.81$; RMSEP boot $=$ $1.43^{\circ} \mathrm{C}$ ) (Nazarova et al., 2015) based on a modern calibration data set of 193 lakes and 162 taxa from East and West Siberia $\left(61-75^{\circ} \mathrm{N}, 50-140^{\circ} \mathrm{E}, \mathrm{T}_{\text {July }}\right.$ range $1.8-18.8^{\circ} \mathrm{C}$ ) (Nazarova et al., 2008; Nazarova et al., 2011; Nazarova et al., 2015). $\mathrm{T}_{\text {July }}$ for the lakes from the calibration data set was derived from New et al. (2002). The $\mathrm{T}_{\text {July }}$ model previously applied for paleo-climatic inferences in East Siberia and Russian and European Arctic demonstrates high reliability of the reconstructed parameters (Syrykh et al., 2017; Nazarova et al., 2017c; Plikk et al., 2019; Nazarova et al., 2020). Chironomid-based reconstruction was performed in C2 version 1.7.7 (Juggins, 2007). The data were square-rooted to stabilize species variance.

In order to capture the diversity of the chironomid communities that is necessary for a reliable temperature 
reconstruction we aimed at extracting at least 50 chironomid larval head capsules (HC) from each sample (Heiri and Lotter, 2001; Larocque, 2001), though as low as 30 head capsules can be enough for assessing dominant environmental trends (Quinlan and Smol, 2001). The profiles SOB18-06 and SOB18-01 contained mostly sufficient numbers of HC, apart from the samples SOB18-06-18, SOB18-01-02 and SOB18-01-01, where chironomids were not found. The profile SOB18-03 contained very low concentration of chironomid samples (2-14 HC). Therefore, chironomids from this profile were used for qualitative ecological reconstruction while quantitative air temperature reconstruction should be considered with caution. The reliability of the chironomid-inferred temperature reconstruction was assessed by two methods. First, the percentages of the fossil chironomid taxa that are absent or rare in the modern calibration dataset were calculated. A taxon is considered to be rare in the dataset when it has a Hill's N2 below 5 (Hill, 1973). The environmental optima of taxa that are rare in the modern dataset are likely to be poorly estimated (Brooks and Birks, 2000). Second, to determine whether the modern calibration models had adequate analogues for the fossil assemblages, the modern analogue technique (MAT) was performed using C2 version 1.7.7 (Juggins, 2007), with squared chord distance as the dissimilarity coefficient (DC) (Overpeck et al., 1985). Confidence intervals were based on minimum DC distance within the calibration sets (Laing et al., 1999). Fossil assemblages above the $95 \%$ confidence interval were considered to have no analogues in the calibration set; while assemblages with the confidence interval between 75 and $95 \%$ were considered to have fair analogues (Francis et al., 2006; Solovieva et al., 2015; Palagushkina et al., 2017).

\section{Diatom Analysis}

Diatom samples were prepared in a water bath following Battarbee (1986). High-refractive Naphrax resin was used for the production of permanent slides. The diatom species identification followed international and Russian literature (Zabelina et al., 1951; Krammer and Lange-Bertalot, 1986; Krammer and Lange-Bertalot, 1988; Krammer and LangeBertalot, 1991a; Krammer and Lange-Bertalot, 1991b). Specimen counts followed parallel transects across the slide under light microscope Zeiss Axioplan and immersion oil. However, specimen counts remained generally low and far below 300 individuals per sample that are commonly used for quantitative interpretations and the potential application of transfer functions. Instead, the ecological characteristics of single species findings are described in relation to habitat preference, salinity, $\mathrm{pH}$ of the host water, geographical distribution, and water velocity (Barinova et al., 2006) and $\mathrm{T}_{\text {July }}$ (Pestryakova et al., 2018), but should not be overinterpreted due to the limited dataset.

\section{RESULTS}

\section{Paleo-Vegetation}

The cluster analysis of the Sobo-Sise Yedoma pollen record results in three units, which correspond to the cryolithological units A-C that were previously defined by Wetterich et al. (2020) of MIS 3, MIS 2 and MIS 1 age, respectively (Figure 3).

Pollen spectra of MIS 3 (Unit A, 52-28 cal kyr BP) are characterized by high percentages of herbaceous pollen with the prevalence of sedge (up to 70\%) and grass (up to 53\%). Deciduous trees and shrubs were represented by Salix whose abundance increased after $39.3 \mathrm{cal} \mathrm{kyr}$ BP. Betula sect. Apterocaryon (dwarf birches) and Alnus subg. Alnobetula (shrubby alder species), however, remain in low abundance. Rubus chamaemorus appeared at $44.1 \mathrm{cal} \mathrm{kyr} \mathrm{BP}$ and became an abundant taxon after $39.3 \mathrm{cal} \mathrm{kyr} \mathrm{BP}$ and until the Holocene. To estimate the presence of conifers in the past vegetation we have used not only percentages but also estimated the pollen concentrations. These are independent of the total percentage indicator. Only for conifers, the concentration numbers showed a different picture compared to percentages throughout the entire record. While the percentages of Pinus sylvestris in Unit A are similar to its respective concentrations, suggesting its real low abundance in the vegetation, the concentrations of Larix are more representative than the Larix pollen percentages because Larix pollen tends to accumulate directly on the site. The entire record of Unit A reveals both relatively high percentages and concentrations of Picea. Another characteristic feature of Unit A is the constant presence of green algae Botryococcus and Pediastrum remnants; an indicator of freshwater ponds close to the site.

The MIS 2 (Unit B, 28-15 cal kyr BP) pollen spectra are similar to those of Unit A, but differ by lower pollen concentrations, lower abundances of sedge and grass and increased Artemisia pollen. The concentration of Larix decreased. All these features are characteristic for more arid conditions than in Unit A. MIS 2 landscapes in the eastern Lena Delta were dominated by steppe-like communities.

The MIS 1 (Unit C, 7-0 cal kyr BP) pollen composition differs sharply from those of units A and B by increased total pollen concentrations, and high percentages and concentrations of arboreal pollen. The main feature is the dominance of dwarf birch (Betula sect. Apterocaryon) as well as the significant amount of alder (Alnus subg. Alnobetula), and Ericaceae pollen. The percentages of Poaceae, Cyperaceae and Artemisia significantly decreased, while the concentrations of all conifers sharply increased. Green algae are absent in Unit C.

\section{Mammoth Fauna}

Bone findings of the Mammoth fauna are commonly rare on Sobo-Sise Island and mostly found below the Yedoma cliff. Only Grigoriev (1988) mentions a "bone horizon" at about 13-15 m arl. In 2018, during fieldwork bones of Mammoth fauna species were found in fresh slump debris well above the beach level are thought to originate from the cliff. According to Kuznetsova et al. (2019) such bones findings are classified as group $\mathrm{C}$ bone fossils whose original position can be related to the outcrop above. The preservation of vivianite (bluish crystals and accretions of hydrated iron phosphate that might form under anoxic conditions on bone material; Guthrie, 1990; Rothe et al., 2016) on some bones supports our assumption that the bones originated from the Sobo-Sise Yedoma cliff. In total, 11 bone 


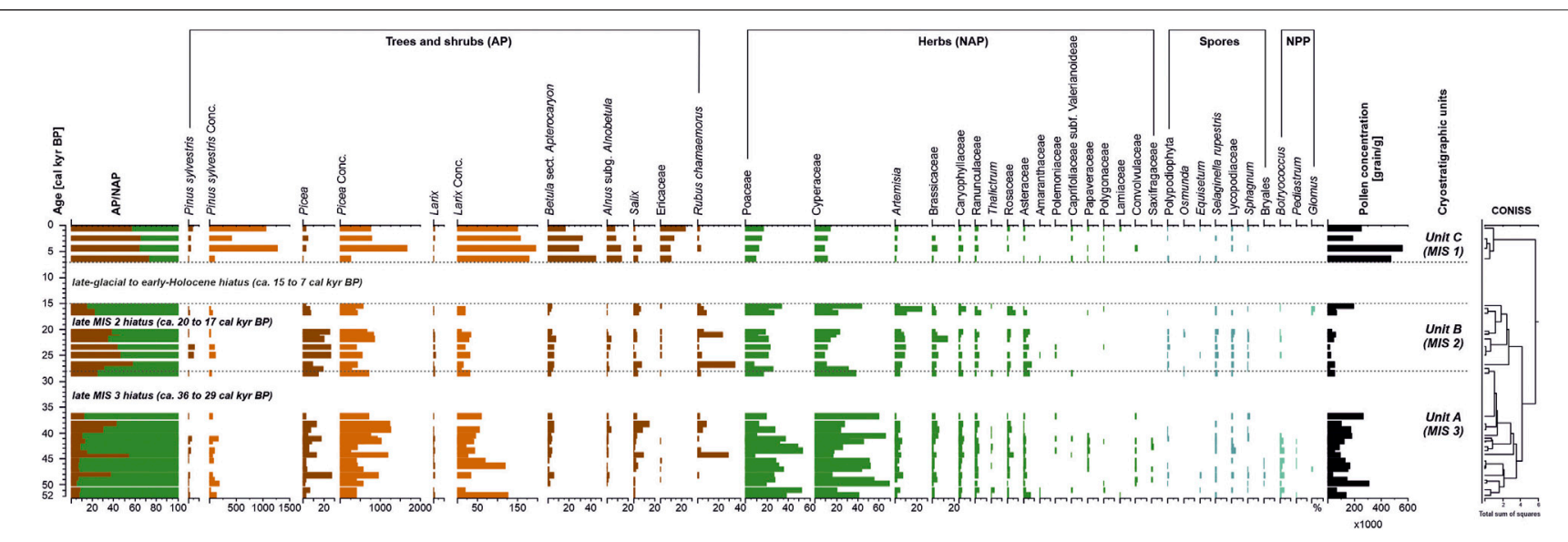

FIGURE 3 | Pollen diagram of the Sobo-Sise Yedoma record. For several taxa the concentrations (Conc.) are given (grain/g x1,000). AP - arboreal pollen, NAP non-arboreal pollen, NPP - non-pollen palynomorphs.

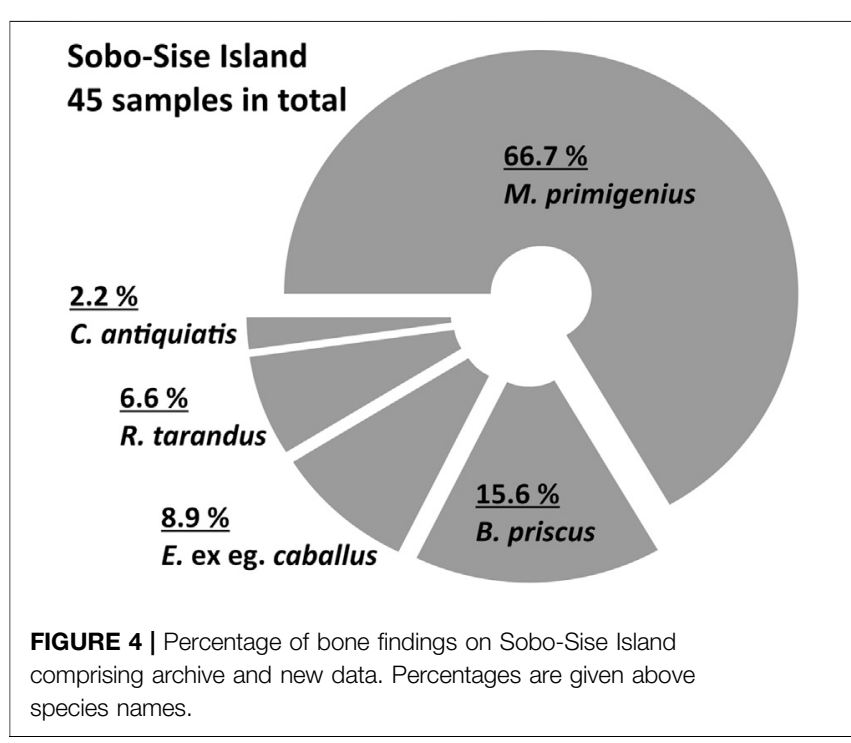

fragments were obtained (Table 1; Supplementary Table S1) and are currently stored at the Lena Delta Reserve Tiksi (Russia). Six bones belong to Mammuthus primigenius (BLUMENBACH, 1799), three to Rangifer tarandus L., 1758 and one to Bison priscus (BOJANUS, 1827) and Coelodonta antiquitatis (BLUMENBACH, 1799) each. One tusk fragment (SOB18bone-02; M. primigenius) was radiocarbon dated to $13,668 \pm$ 57 yr BP (16,520 cal yr BP; Table 2; Wetterich et al., 2020).

It should be noted that bones of $R$. tarandus might belong to modern representatives of this species. Despite the low number of bone findings from the present study, main features of such bone collections of the West Beringian Mammoth fauna (Sher et al., 2005; Kuznetsova et al., 2019) are represented. Those are the prevalence of mammoth bones and the presence of other large grazers such as horse and bison. The finding of woolly rhinoceros remains is somewhat remarkable as it has not been found in the Lena Delta records so far (Wetterich et al., 2008a; Kuznetsova et al., 2019). In addition to the recent bone collection we consider further unpublished data of mammal bones from Sobo-Sise Island stored in several collections in Russia. First bone findings on extinct Mammoth fauna species on Sobo-Sise Island were obtained in July 19-20, 1927 by the Hunting and Fishing Team of the Yakut Expedition (A. Romanov). In total 18 bone samples from Sobo-Sise were transferred in 1928 to the Zoological Institute of the Russian Academy of Sciences (ZIN RAS) in St. Petersburg (Russia). This collection comprises three species that are M. primigenius, B. priscus and Equus ex eg. caballus. Mammoth is represented by 11 bones of which most probably eight belong to the same skeleton (cervical vertebrae, left heel bone and fragments of the lower jaw, tusk, left branch of pelvis, left femur, left humerus) because those were collected at one location - the thawing slope of a conical thermokarst mound (baidzherakh) at a lake shore. Six bison bones (two cervical vertebrae and four skull fragments) and one horse bone (third phalanx) complement this collection (Table 1).

In 1988, the first radiocarbon date on bone material from Sobo-Sise was published where a tusk fragment found in situ at about $13-15 \mathrm{~m}$ arl revealed an age of $14,340 \pm 120 \mathrm{yr} \mathrm{BP}$ (17,490 calyr BP; GIN-4115) (Grigoriev, 1988). Another mammoth bone found on Sobo-Sise was dated to $24,400 \pm$ $650 \mathrm{yr}$ BP $(28,620 \mathrm{cal} \mathrm{yr}$ BP; IM-835) although no further information is available (Table 2). Six bones were found on Sobo-Sise in 1998 in course of the Russian-German Expedition "Lena Delta," of which five belong to mammoth (one skull fragment, two rib fragments and two vertebral fragments) and one to horse (humerus fragment). One mammoth rib fragment (MKh-O621) was radiocarbon-dated to $19,200 \pm 220 \mathrm{yr} \mathrm{BP}$ $(23,180 \mathrm{cal}$ yr BP; GIN-10235) and one mammoth vertebral fragment (MKh-O624) to $>45,000 \mathrm{yr}$ BP (GIN-13929, GrA 46013) (Table 2).

The bone collection of the Lena Delta Reserve Tiksi (Russia) contains eight mammoth bones collected on Sobo-Sise in 1990 and identified in 2005 by T.V. Kuznetsova (MSU, Russia) as forearm bones (radius and ulna), two fragments of tibia and fragments of cervical vertebra, vertebra, right branch of pelvis, 


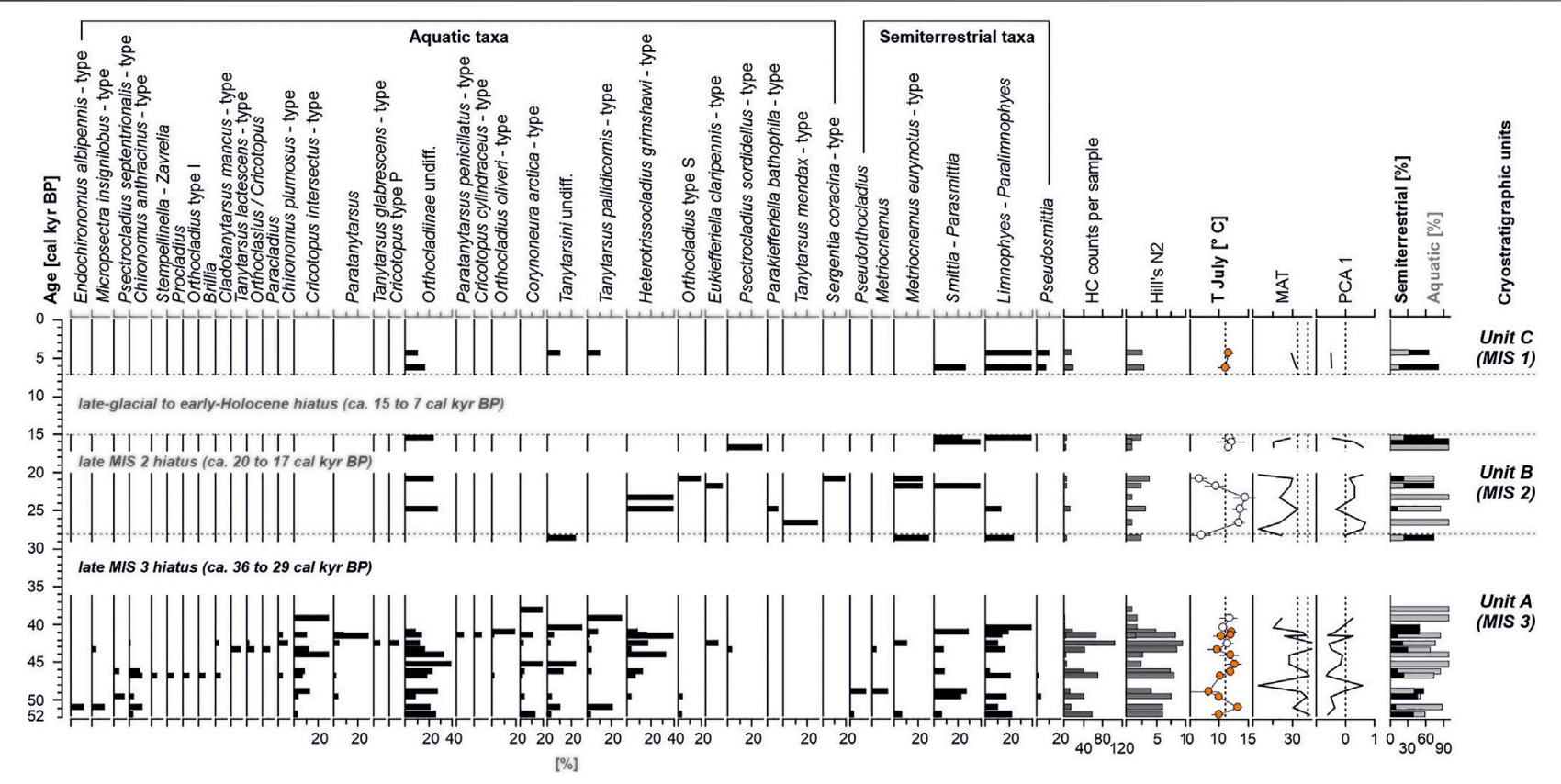

FIGURE 5 | Chironomid diagram of the Sobo-Sise Yedoma record. HC - head capsule, MAT - Modern Analogue Technique, PCA 1 - first axis of the principal component analysis. The dotted line in the reconstruction $\mathrm{T}_{\text {July }}$ reconstruction indicates the modern value of $11^{\circ} \mathrm{C}$. The dotted lines in the MAT indicate the $75 \%(30.40)$ and $95 \%$ (34.97) confidence intervals. Note that hollow symbols of the reconstructed $\mathrm{T}_{\text {July }}$ are based on low HC concentrations and should therefore be considered with caution.

heel bone. Two more horse bones were found in 2000 and identified as the damaged shoulder blade and the right branch of pelvis. A sample of a mammoth forearm (LDR-O299) from this collection was radiocarbon-dated to $17,070 \pm 70 \mathrm{yr} \mathrm{BP}$ $(20,630 \mathrm{calyr}$ BP; KIA-32839). The overall collection of Mammoth fauna bones from Sobo-Sise in various years comprises 45 specimens (Figure 4): M. primigenius - $66.7 \%$ (30 specimens), B. priscus - 15.6\% (7 specimens), E. ex gr. caballus - $8.9 \%$ (4 specimens), $R$. tarandus - $6.6 \%$ (3 specimens) and C. antiquitatis - $2.2 \%$ (1 specimen) (Figure 4). The sparse available radiocarbon dates of $M$. primigenius comprise five finite and one infinite ages. Two ages fall into the MIS 3 interstadial period and four into the MIS 2 stadial (Table 2).

\section{Paleo-Limnology}

The chironomid record of the Sobo-Sise Yedoma record exhibits three zones, which delineate the cryolithological stratification into three units A-C covering MIS 3 to MIS 1 (Figure 5). The chironomid fauna of the record comprises 39 taxa. The number of chironomid HC per sample varies considerably with highest concentration found in Unit A, while units B and C show relatively low concentrations. All fossil chironomid taxa were represented in the modern training sets. Only three taxa that had only single occurrence in the investigated profiles have Hill's N2 $<5$ in the training set and therefore were defined as not wellrepresented in the NR training sets and model: Orthocladius/ Cricotopus (N2 = 1.9 in the SOB samples and 0 in the NR training set), Pseudorthocladius (N2 $=1.8$ in the SOB samples and 4.0 in the NR training set), Tanytarsus lactescens-type (N2 = 1 in the SOB samples and 1 in the NR training set). The low representation of these taxa in the SOB profiles does not hamper the quality of the reconstruction. MAT for $\mathrm{T}_{\text {July }}$ reconstruction revealed that the samples from the interval 43.3-42.5 cal kyr BP had no analogues in the calibration set (MAT above 95\%; Figure 5). The remaining profile samples have good or fair analogue in the NR training set. The high representation of the taxa in the training set, together with the predominantly good MAT statistics results, indicated that the temperature reconstruction from the investigated profiles is mainly reliable. Samples with poor MAT tests should be interpreted with caution.

The MIS 3 chironomid fauna of Unit A (52-28 cal kyr BP) is composed of 36 taxa, while their diversity (N2) varies considerably. Several periods within Unit A exhibit rich chironomid fauna: 52 to $49 \mathrm{cal} \mathrm{kyr} \mathrm{BP,} 48$ to $46 \mathrm{cal} \mathrm{kyr} \mathrm{BP}$ and 43 to $40 \mathrm{cal} \mathrm{kyr}$ BP (median $\mathrm{N} 2=8.9$; Figure 5). The representation of typical aquatic taxa vs. semiterrestrial taxa varies within unit A. Between 52 and $49 \mathrm{cal} \mathrm{kyr} \mathrm{BP}$ the communities are dominated by taxa characteristic for moderate climatic conditions: Endochironomus albipennis-type, Micropsectra insignilobus-type, Chironomus anthracinus-type, Tanytarsus pallidicornis-type and Cricotopus interectus-type. The reconstructed $\mathrm{T}_{\text {July }}$ varies around modern level $\left(11^{\circ} \mathrm{C}\right)$ with one excursion of about $1.5^{\circ} \mathrm{C}$ above modern $\mathrm{T}_{\text {July }}$ at 50.8 cal kyr BP. The decline of semiterrestrial taxa at the same time might indicate higher water level under relatively warm conditions. Later on, until about $49 \mathrm{cal} \mathrm{kyr} \mathrm{BP}$ the share of 
semiterrestrial taxa reaches up to $57 \%$ and the reconstructed $\mathrm{T}_{\text {July }}$ declines to about $1^{\circ} \mathrm{C}$ below modern. Such cooling might have induced shallowing of the water level by reducing the seasonally thawed uppermost ground below the ponds. Between 48 and $38 \mathrm{cal}$ kyr BP, the chironomid fauna is dominated by typical aquatic taxa although chironomid counts and diversity decrease considerably between 46 and $44 \mathrm{cal}$ kyr BP when the reconstructed $\mathrm{T}_{\text {July }}$ rises up to $1.5^{\circ} \mathrm{C}$ above modern. The period between 44 and $41.5 \mathrm{cal} \mathrm{kyr} \mathrm{BP}$ is characterized by the highest diversity and concentration of chironomids. The communities are dominated by the Heterotrissocladius grimschawi-type that occurs in oligotrophic lakes and is indicative of moderate conditions with temperature optima of $11-12^{\circ} \mathrm{C}$. Reconstructed $\mathrm{T}_{\text {July }}$ slightly varies around modern with warmer-than-today $\mathrm{T}_{\text {July }}$ around $41 \mathrm{cal} \mathrm{kyr} \mathrm{BP.} \mathrm{After} 41.5 \mathrm{cal} \mathrm{kyr} \mathrm{BP}$, a strong decline of chironomid communities is observed and also reflected in the PCA 1 sample scores. Between 40.4 and 38 cal kyr BP only few chironomid remains have been found. Semiterrestrial taxa disappear around $39 \mathrm{cal} \mathrm{kyr} \mathrm{BP}$ probably indicating another episode of a higher water level. At $36.7 \mathrm{cal} \mathrm{kyr}$ BP no chironomids have been found in the sediments, which probably suggest another dry out. Above the hiatus, the uppermost sample from Unit A (SOB18-03-03) is dated to $28.4 \mathrm{cal}$ kyr BP. Here, the chironomid fauna is poor and is represented mainly by semiterrestrial (LimnophiesParalimnophies, Metriocnemus eurinotus-type) or phytophilic taxa (Tanytarsini). The reconstructed $\mathrm{T}_{\text {July }}$ is of about $8^{\circ} \mathrm{C}$, which is about $3^{\circ} \mathrm{C}$ below modern $\mathrm{T}_{\text {July }}$.

The abundance and diversity of chironomids are generally low during MIS 2 (Unit B, 28 - 15 cal kyr BP). Between 27.7 and $23.3 \mathrm{cal}$ kyr BP, the chironomid fauna is dominated by aquatic taxa (Tanytarus mendax-type, Heterotrissocladius grimschawi-type). After $21.8 \mathrm{cal}$ kyr BP the proportion of semiterrestrial taxa rise and taxa characteristic for littoral zone of lakes (Eukiefferiella claripennis-type) and for cold environments (Orthocladius type $\mathrm{S}$, Sergentia coracina-type) appear. In the sediment layer dated to $20.4 \mathrm{cal}$ kyr BP no chironomid remains have been found. The samples between 16.7 and $15.4 \mathrm{cal} \mathrm{kyr} \mathrm{BP}$ are represented either by littoral phytophilic and acidophilic Psectrocladius sordidellus-type or by the typical semiterrestrial Smittia-Parasmittia, LimnophiesParalimnophies-types that are both indicative for unstable water levels and erosion processes.

In MIS 1 (Unit C, 7 - 0 cal kyr BP) chironomid remains were found only between 6.4 and $4.4 \mathrm{cal} \mathrm{kyr} \mathrm{BP}$. The chironomid fauna is poor (median N2 $=2.9$ ) and dominated by semiterrestrial taxa such as Smittia-Parasmittia, and Limnophies-Paralimnophies in presence of the phytophilic Tanytarsini taxa. The reconstructed $\mathrm{T}_{\text {July }}$ at $6.4 \mathrm{cal} \mathrm{kyt} \mathrm{BP}$ is at modern level $\left(11.1^{\circ} \mathrm{C}\right)$ with a slight increase toward $4.4 \mathrm{cal} \mathrm{kyr} \mathrm{BP}\left(11.7^{\circ} \mathrm{C}\right)$. After $4.4 \mathrm{cal} \mathrm{kyr} \mathrm{BP}$ chironomids are absent from the record. Diatom fossil valves were only found in three samples of the uppermost unit $\mathrm{C}$ after $6.4 \mathrm{cal} \mathrm{kyr} \mathrm{BP}$. Highest counts were found in the uppermost sample SOB18-01 with 185 specimens, while sample SOB18-01-02 contained only five specimens. The diatom flora of the SoboSise Yedoma record is represented by 25 taxa, belonging to 17 genera (Supplementary Table S2) and dominated by benthic species (Supplementary Table S3) while benthic-planktonic species occur much less and planktonic species are absent from the record. Most of the diatom species are indifferent to salinity. Alkaliphilic and alkalibiontic species dominate the record and most of the diatom species are cosmopolitans while boreal species are present with Hannaea arcus and Pinnularia alpina, and arcticalpine species with Pinnularia gibba and Navicula vulpina. Flowvelocity preferences are known for 19 species of the 25 species identified in the Sobo-Sise record. Nine of them are indifferent, six species indicate flowing water and three standing water. Overall, the diatom flora of Unit $\mathrm{C}$ indicates the presence of shallow water with low salinity and neutral $\mathrm{pH}$. The low representation of diatoms in the record might point to low silica availability in the host water or generally aquatic conditions not suitable to maintain stable diatom communities. For the normal development of diatoms, a rather significant concentration of silica is required, which is used for building of their frustules (Wasser et al., 1989). In the absence or lack of silica, the diatom frustules become thinner, and when the concentration of silicon in water falls below $0.3 \mathrm{mg} \mathrm{L}^{-1}$, the growth of diatoms completely stops (Proshkina-Lavrenko, 1974; Martin-Jézéquell, Lopez, 2003).

\section{DISCUSSION}

\section{Paleo-Ecology of the Sobo-Sise Yedoma Cliff in Regional Context}

Detailed paleo-ecological information has been obtained from Yedoma IC deposits and its Holocene cover from two nearby locations on Bykovsky Peninsula (outcrop Mamontova Khayata) and Kurungnakh-Sise Island in the central Lena Delta (Figure 1). The Bykovsky Yedoma archive has been intensively studied for pollen, plant macrofossils, testate amoebae, freshwater ostracods, fossil insect remains and mammal bones of the late Pleistocene Mammoth fauna (Schirrmeister et al., 2002a; Bobrov et al., 2004; Kienast et al., 2005; Sher et al., 2005; Wetterich et al., 2005; Andreev et al., 2011; Kuznetsova et al., 2019) based on well-described cryolithological properties of the frozen deposits with well-established radiocarbonbased chronology (Schirrmeister et al., 2002b). The Yedoma IC and its stratigraphic context of fluvial sands underneath and Holocene cover on top exposed at the shore of Kurungnakh-Sise Island has been studied in terms of paleo-ecology of pollen, plant macrofossils, testate amoebae, ostracods, insect fossil remains and fossil mammal bones in detail by Schirrmeister et al. (2003) and Wetterich et al. (2008a). Main paleo-ecological results from both locations are discussed in comparison to those from the present study on Sobo-Sise Island below for the MIS 3 interstadial, the MIS 2 stadial and the MIS 1 interglacial periods.

\section{Interstadial MIS 3 Environments}

The new pollen record from Sobo-Sise Island matches those from Bykovsky Peninsula (Andreev et al., 2002; Schirrmeister et al., 2002a) and Kurungnakh-Sise Island (Schirrmeister et al., 2003; Wetterich et al., 2008a) and is further supported and enhanced by plant macrofossil studies from Bykovsky Peninsula (Kienast et al., 2005) and Kurungnakh-Sise Island (Wetterich et al., 2008a). The regional vegetation during MIS 3 as reconstructed from pollen and plant macrofossils of Yedoma IC deposits is characterized 
tundra-steppe vegetation with dominance of Cyperaceae and Poaceae pollen and some amounts of Artemisia and Salix between 53 and $43 \mathrm{cal} \mathrm{kyr} \mathrm{BP.} \mathrm{High} \mathrm{abundance} \mathrm{of} \mathrm{these} \mathrm{taxa}$ and presence of Caryophyllaceae as well as generally higher pollen concentrations are noted between 40 and $36 \mathrm{cal} \mathrm{kyr} \mathrm{BP.}$ The permanent presence of Salix pollen points to the occurrence of willow shrubs in more protected and wet places. Low percentages and low concentrations of Pinus sylvestris point to low abundance in the past vegetation. In contrast, Larix shows a distinct difference with low percentages but high concentrations. Assuming that Larix tends to accumulate directly on the site, we deduce that Larix pollen concentrations are more representative than the Larix pollen percentages. We therefore suggest that Larix was a member of plant communities associated with Unit A and Pinus sylvestris pollen were rather derived from long-distance transport. The entire record of Unit A reveals relatively high percentages and concentrations of Picea. Since it is difficult to assume suitable conditions for spruce in the late Pleistocene of the Lena Delta region, we have to conclude that this is redeposition driven by wind or river transport. The redeposition in situ is also possible, however, age-height modeling did not reveal any inversions within Unit A (Wetterich et al., 2020). Stagnant water is indicated by the presence of green algae Botryococcus and Pediastrum remains. The Bykovsky and Kurungnakh-Sise records both show that remains of typical steppe and meadow plants of the Festuca, Kobresia, Linum, Silene, and Potentilla genera (Kienast et al., 2005) as well as wetland plants such as Carex sect. Phacocystis, Saxifraga hirculus, and Eriophorum angustifolium are common in the fossil record. At about $51 \mathrm{cal} \mathrm{kyr} \mathrm{BP}$ and $40 \mathrm{cal} \mathrm{kyr} \mathrm{BP}$ in the Bykovsky record, the occurrence of the temperate aquatic plant Callitriche hermaphroditica provides evidence of mean $\mathrm{T}_{\text {July }}$ of $12^{\circ} \mathrm{C}$ or more, while the finding of the steppe taxon Thesium dated to 51 cal kyr suggests $\mathrm{T}_{\text {July }}$ of $15^{\circ} \mathrm{C}$ or more. The chironomid-based $\mathrm{T}_{\text {July }}$ reconstruction for MIS 3 from the Sobo-Sise Yedoma record shows some variation (Figure 5) and points to warmer-thantoday $\left(>11^{\circ} \mathrm{C}\right)$ temperatures at about $51 \mathrm{cal} \mathrm{kyr} \mathrm{BP,} \mathrm{46-44} \mathrm{and}$ 41 cal kyr BP showing a general agreement with the plant macrofossil-based $\mathrm{T}_{\text {July }}$ estimates from the Bykovsky Yedoma record (Kienast et al., 2005). Interstadial climate variability during MIS 3 has been previously deduced from proxy records across West Beringia (Anderson and Lozhkin, 2001) although with regional differences in the onset and duration of climatic optimum conditions (Wetterich et al., 2014). Those were recorded on Kurungnakh-Sise Island between 43 and $36 \mathrm{cal} \mathrm{kyr}$ BP and on Bykovsky Peninsula 45-38 cal kyr BP (Wetterich et al., 2014 and references therein). Thus, the Sobo-Sise chironomid record supports warmer-than-today summers as recorded in the Bykovsky and Kurungnakh-Sise Yedoma archives given dating uncertainties and different proxies. $\mathrm{T}_{\text {July }}$ reconstructions from the western part of the Yana-Indigirka lowland (east of the study area) reveal similarto or warmer-than-today temperatures (by up to $4-4.5^{\circ} \mathrm{C}$ ) and higher-than-today annual precipitation (by up to $50-100 \mathrm{~mm}$ ) between about 39 and 31 cal kyr BP (Pitulko et al., 2017), although older deposits are not captured in this record starting at 39.2 cal kyr BP. The early MIS 3 warmer-than-today conditions are represented by the Bykovsky and Sobo-Sise data, while late MIS 3 deposits are missing in these records and the Yana-Indigirka Lowland data misses the early MIS 3 deposits but represent the late MIS 3 phase of warmer (and moister)-thantoday summer conditions in western Beringia.

The regional MIS 3 interstadial environments and vegetation as reconstructed from pollen data provided favorable conditions to maintain the Mammoth fauna as seen in the Bykovsky records (Schirrmeister et al., 2002a; Sher et al., 2005; Kuznetsova et al., 2019), but also supported by Sobo-Sise record with one radiocarbon-dated mammoth bone of $28,620 \mathrm{cal} \mathrm{yr} \mathrm{BP}$ (Table 2).

The aquatic conditions during MIS 3 are reflected by the chironomid data from the Sobo-Sise Yedoma. Varying dominance of aquatic and semiterrestrial taxa over time represent the transition from higher to shallower water levels (Nazarova et al., 2017a). However, the supposed main freshwater type of the Beringian tundra-steppe environments are ice-wedge low-center polygon ponds which rarely exceed $1 \mathrm{~m}$ water depth in modern tundra landscapes (Wetterich et al., 2008b). The onset of ice-wedge polygon development with shallow ponds is represented by prevailing semiterrestrial chironomid taxa between 52 and $48 \mathrm{cal} \mathrm{kyr} \mathrm{BP.} \mathrm{Evolving} \mathrm{low-center} \mathrm{polygons}$ during MIS 3 climatic optimum with warmer-than-today $\mathrm{T}_{\text {July }}$ likely induced deeper thaw and thus higher water level in the ponds that explains the higher share of aquatic chironomid taxa from 48 to 36 cal kyr BP. Freshwater ostracod fossil findings with highest abundance and diversity recorded at about $44 \mathrm{cal}$ kyr BP on Kurungnakh-Sise Island (Wetterich et al., 2008a) support the existence of permanent water bodies. The Bykovsky ostracod record is more diverse and its best representation spans from about 48 to $41 \mathrm{cal} \mathrm{kyr} \mathrm{BP} \mathrm{(Wetterich} \mathrm{et} \mathrm{al.,} \mathrm{2005).} \mathrm{Later} \mathrm{on} \mathrm{the}$ ostracod fauna in the Bykovsky Yedoma record vanishes toward the MIS 3-2 transition, and in the Sobo-Sise chironomid record the uppermost sample at $28 \mathrm{cal} \mathrm{kyr} \mathrm{BP}$ after the hiatus at 36-29 cal kyr BP exhibits a poor representation of only semiterrestrial taxa. Both dynamics reflect deterioration of the aquatic habitats in polygon ponds, probably induced by cooling at the MIS 3-2 transition leading to shallowing or dry-out of the water bodies.

\section{Stadial MIS 2 Environments}

The pollen-based paleo-vegetation records from Sobo-Sise Island and from Bykovsky Peninsula both highlight open tundra-steppe with prevailing Poaceae with present Cyperaceae, Artemisia, Brassicaceae and Caryophyllaceae pollen (Schirrmeister et al., 2002a; Andreev et al., 2002; Andreev et al., 2011) while MIS 2 deposits are largely missing in the Kurungnakh-Sise sequence (Schirrmeister et al., 2003; Wetterich et al., 2008a). MIS 2 pollen concentrations are generally lower than during MIS 3. Selaginella rupestris spores indicate very dry habitats, while larger amounts of reworked Pinaceae pollen and Glomus spores indicate disturbed soils due to the presence of large grazers of the Mammoth fauna. Such pollen composition reflects rather cold and dry summer climate conditions if compared to MIS 3. The Larix concentrations are low suggesting colder summers than during MIS 3. Still present green algae Botryococcus and Pediastrum remains point to the occasional presence of lowcentred polygons while the absence of aquatic plant macro-fossils 
in deposits dated to $26.3 \mathrm{cal} \mathrm{kyr} \mathrm{BP}$ (Kienast et al., 2005) suggests unstable aquatic environments during MIS 2. Dominating arctic pioneer species and decreased floristic diversity of the plant macro-fossil record point to harsh summer climate.

Evidence for subsistence of the Mammoth fauna during the MIS 2 stadial is found in four mammoth radiocarbon dates from Sobo-Sise Island ranging from 23,180 to $16,520 \mathrm{cal} \mathrm{yr} \mathrm{BP}$ (Table 2) and corresponding to comparable data from Bykovky Peninsula in regional context (Schirrmeister et al., 2002a; Sher et al., 2005; Kuznetsova et al., 2019). Interestingly, one age of 17,490 cal yr BP falls into the MIS 2 sedimentary hiatus (20 - $17 \mathrm{cal}$ yr BP) as estimated in the Sobo-Sise record sampled in 2018 (Wetterich et al., 2020) although a lack of deposits in a sequence due to hampered deposition or post-depositional erosion does not necessarily indicate a lack of past wildlife.

Cold and dry summer climate with unstable aquatic conditions is further seen in the chironomid record of Sobo-Sise with very low concentrations and diversity during the entire MIS 2 unit. Aquatic

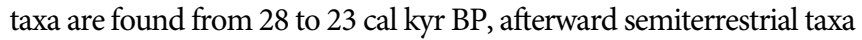
prevail. The period from 17 to $15 \mathrm{cal} \mathrm{kyr} \mathrm{BP}$ is characterized by littoral phytophilic and acidophilic taxa as well as by typical semiterrestrial taxa. The ostracod record from the Bykovsky Yedoma lacks findings in the MIS 3-2 transition period from 32 to $25 \mathrm{cal} \mathrm{kyr} \mathrm{BP} \mathrm{(zone} \mathrm{III} \mathrm{in}$ Wetterich et al., 2005) and was interpreted as extremely unfavorable conditions for aquatic life due to dry-out of polygon ponds. Starting from about $25 \mathrm{cal}$ kyr BP until about $21 \mathrm{cal} \mathrm{kyr} \mathrm{BP}$ the ostracod record from Bykovsky is poor in abundance and diversity and no ostracods were found after $21 \mathrm{cal} \mathrm{kyr}$ BP. Improved aquatic conditions and present ostracod fossils are seen in a sample dated to $16.9 \mathrm{cal} \mathrm{kyr} \mathrm{BP.} \mathrm{MIS} 2$ aquatic conditions as seen in chironomids from Sobo-Sise and ostracods from Bykovsky point to shallow polygon ponds or just wet polygon centers due to low summer precipitation feeding the water bodies and cold summer temperatures causing shallow thaw depth and inhibited ground ice melt. Due to the unfavorable aquatic conditions and the resulting poor chironomid record, the chironomid-based $\mathrm{T}_{\text {July }}$ reconstruction for MIS 2 relies on very low concentration of chironomids in sediments (Figure 5) and its reliability is therefore limited. Therefore, warmer-than-today $\mathrm{T}_{\text {July }}$ as seen in the chironomid record between 27 and $23 \mathrm{cal} \mathrm{kyr} \mathrm{BP}$ seems unlikely to represent MIS 2 conditions. However, the coldest $\mathrm{T}_{\text {July }}$ up to about $4^{\circ} \mathrm{C}$ below modern is found at about $20 \mathrm{cal} \mathrm{kyr} \mathrm{BP}$ (Figure 5). This reconstructed low $\mathrm{T}_{\text {July }}$ is caused by a high representation of indicative for colder conditions chironomid taxa like Orthocladius type $S$ (T optimum in the NR model $9.5^{\circ} \mathrm{C}$ ) and Metriocnemus eurinotus-type (T optimum in the NR model $9.2^{\circ} \mathrm{C}$ ) (Nazarova et al., 2015).

\section{Interglacial MIS 1 Holocene}

In the Sobo-Sise record, the Holocene pollen spectra of Unit C differ noticeably from those of the late Pleistocene Yedoma IC units A and $\mathrm{B}$, and are characterized by dominating Betula sect. Apterocaryon and the significant amounts of Alnus subg. Alnobetula and Ericaceae pollen, all together indicating humid shrub-tundra vegetation after about 7 cal kyr BP with isolated Larix stands. The increased concentration of Pinus sylvestris and Picea can be a result of long-distance transport of Holocene coniferous forests located south of the Lena Delta (Müller et al., 2009). The pollen records of the Holocene cover deposits of the Bykovsky Yedoma and the Kurungnakh-Sise Yedoma span from about $9.2 \mathrm{cal} \mathrm{kyr} \mathrm{BP}$ to modern and from about 9.1 to $2.9 \mathrm{cal} \mathrm{kyr} \mathrm{BP}$, respectively. These records differentiate into early to middle Holocene and late Holocene pollen zones (Schirrmeister et al., 2002b; Wetterich et al., 2008a). The early Holocene pollen spectra indicate shrubtundra (or forest tundra) vegetation dominated by Alnus subg. Alnobetula, Betula sect. Apterocaryon and Salix as well as by Ericales with some Cyperaceae and Poaceae until about $8.4 \mathrm{cal} \mathrm{kyr} \mathrm{BP}$ (Andreev et al., 2011). After $8.4 \mathrm{cal} \mathrm{kyr} \mathrm{BP}$ the shrub-tundra gradually disappears and is replaced by modern high Arctic and Arctic tundra vegetation. The plant macrofossil record from Bykovsky comprises two records dated to about 8.6 and $3 \mathrm{cal} \mathrm{kyr} \mathrm{BP.} \mathrm{Warmer} \mathrm{summers} \mathrm{are} \mathrm{reflected} \mathrm{by} \mathrm{the} \mathrm{early} \mathrm{Holocene}$ plant species composition while the late Holocene record points to increased humidity and decreased summer temperatures by a smaller share of cryoxerophilous pioneer vegetation and tundrasteppe vegetation and a larger share of tundra bog species. Such Holocene climatic deterioration is seen in prevalence of tundra bog plants, while the occurrence of nival meadow plants such as Saxifraga nivalis and Ranunculus nivalis suggests a short growing season due to a thick snow cover and predominating cool and moist conditions (Schirrmeister et al., 2002b). The absence of true water plant species in the late Holocene and the reduced share of plants inhabiting marshy sites at shallow water lake shores point to impoverishment of aquatic conditions. The plant macrofossil record from Kurungnakh-Sise differentiates into data from the early Holocene dated to about $9.1 \mathrm{cal} \mathrm{kyr} \mathrm{BP}$ and the mid to late Holocene dated to about 6.7 to $2.9 \mathrm{cal} \mathrm{kyr}$ BP (Wetterich et al., 2008a). The early Holocene plant composition comprises tundrasteppe species such as Kobresia myosuroides and Potentilla cf. stipularis while the number of wetland and tundra bog plants is low. Thus, the temperature increase toward the early Holocene is not reflected in these data although a single Betulaceae fruit was found. The pollen data from Kurungnakh-Sise, however, show a clear increase in Betula sect. Apterocaryon, Alnus subg. Alnobetula, Betula sect. Betula, and Ericales pollen as mentioned above. The mid to late Holocene plant species composition from KurungnakhSise reflects wet tundra with wetland sedges such as Carex sect. Phacocystis and dominating willow shrubs. The presence of Betula cf. fruticosa and Ledum palustre suggests subarctic temperature conditions (Wetterich et al., 2008a).

The Holocene chironomid from Unit C of the Sobo-Sise Yedoma record is sparse. Semiterrestrial and phytophilic taxa dominated till ca $4.4 \mathrm{cal} \mathrm{kyr} \mathrm{BP}$ and disappeared thereafter. The composition of chironomid communities indicates the presence of a very shallow overgrown waterbody that dried out after $4.4 \mathrm{cal} \mathrm{kyr} \mathrm{BP.} \mathrm{Rare} \mathrm{diatom}$ fossils were only found within the uppermost samples of the Holocene cover after about $6.4 \mathrm{cal} \mathrm{kyr}$ BP. The dominating ecological preferences of the diatom species are characterized as cosmopolitan, benthic, alkaliphilic, indifferent to salinity. If compared to modern Yakutian diatom reference data with statistically quantified optimum ecological rages of certain conditions (Pestryakova et al., 2018) three species are found in the Holocene Sobo-Sise diatom record. Those are Diploneis elliptica (optimum $\mathrm{T}_{\text {July }}$ of $11.9^{\circ} \mathrm{C}$ ) and Stauroneis anceps (optimum $\mathrm{T}_{\text {July }}$ of $11.2^{\circ} \mathrm{C}$ ) from Unit $\mathrm{C}$ deposits dated from 6.4 to $2.5 \mathrm{cal} \mathrm{kyr} \mathrm{BP.}$ 
Compared to the Holocene chironomid-based $\mathrm{T}_{\text {July }}$ reconstruction of ca $11.5^{\circ} \mathrm{C}$ at 6.4 to $4.4 \mathrm{cal} \mathrm{kyr} \mathrm{BP}$ it seems obvious that the chironomidbased and diatom-based $\mathrm{T}_{\text {July }}$ reconstructions do not contradict each other. The finding of the diatom species Epithemia adnata $\left(\mathrm{T}_{\text {July }}\right.$ $>15^{\circ} \mathrm{C}$ ) in the uppermost sample of Unit C points to warmer conditions than today, while the indication of optimum ion content (expressed as electrical conductivity of $586 \mu \mathrm{sm}^{-1}$ ) of $E$. adnata would support such warm summer temperatures with increased evaporation. Modern electrical conductivity values in polygon ponds in the Lena Delta are more than two-fold lower and range from 27 to $254 \mu \mathrm{s} \mathrm{cm}^{-1}$ (Wetterich et al., 2008b). However, the Sobo-Sise fossil diatom record is very limited and its environmental indication should be interpreted with caution. Ostracod fossils have not been found in the Holocene cover deposits on the Yedoma IC on Bykovsky Peninsula (Wetterich et al., 2005) and Kurungnakh-Sise Island (Wetterich et al., 2008a), but are found on Bykovsky in late Holocene deposits dated to about $3 \mathrm{cal} \mathrm{kyr} \mathrm{BP}$ that accumulated in thermokarst basins here and elsewhere in the region (Wetterich et al., 2009; Morgenstern et al., 2013). Such observation might be explained by landscape reorganization due to massive permafrost thaw starting in the lateglacial period when climate warming toward the Holocene increased thermokarst processes and thus the rates of northern lake formation starting $\sim 14 \mathrm{cal} \mathrm{kyr} \mathrm{BP}$ and peaking around $10.4 \mathrm{cal} \mathrm{kyr}$ BP (Brosius et al., 2021). Although lake formation slowed down around 10-8 cal kyr BP, the major occurrence of Holocene aquatic habitats in West Beringian Yedoma landscapes is found in thermokarst basins evolving since the deglacial rather than on degrading Yedoma uplands.

\section{CONCLUSION}

The regional Yedoma records in the Lena Delta and on Bykovsky Peninsula confirm the existence of late Pleistocene tundra-steppe environments in West Beringia during MIS 3 with partly warmerthan-today summers and wetter conditions allowing for stagnant water (i.e., polygon ponds). During MIS 2, summers were probably colder than during MIS 3 and drier with unstable aquatic conditions in the polygonal landscape. However, the aquatic conditions in shallow ponds of low-center polygons during MIS 3 and MIS 2 were suitable for maintaining chironomid faunae although highly dynamic and prone to episodically dry-out or drainage causing low abundance and diversity of chironomids in the records. Diatom frustules occurred in the sediment record only after $6.4 \mathrm{cal} \mathrm{kyr} \mathrm{BP}$, probably due to post-depositional dissolution processes or to the lack of silica in the earlier period of pond development.

In addition to previous plant macrofossil-based $\mathrm{T}_{\text {July }}$ reconstructions from the Bykovsky Yedoma record available for only two periods around 51 and $40 \mathrm{cal}$ kyr BP, the present chironomid-based $\mathrm{T}_{\text {July }}$ estimates fills the period in between with data from about 52 to $41 \mathrm{cal}$ kyr BP. The record reveals warmerthan-today $\mathrm{T}_{\text {July }}$ at about $51 \mathrm{cal} \mathrm{kyr} \mathrm{BP,46-44}$ and $41 \mathrm{cal} \mathrm{kyr} \mathrm{BP}$ highlighting early MIS 3 climate optimum conditions.

The Sobo-Sise pollen record suggests that Larix was a member of the regional MIS 3 tundra-steppe communities. The Holocene vegetation differentiates into early Holocene shrub-tundra replaced by mid- and late Holocene modern wet tundra.

The finding of a bone from woolly rhinoceros (Coelodonta antiquitatis) most likely originating from the Sobo-Sise Yedoma cliff is somewhat remarkable since the species has not been reported yet from the Lena Delta region or Bykovsky Peninsula, and is generally rare in collections of fossil bones of the late Pleistocene Mammoth fauna in northern part of West Beringia.

\section{DATA AVAILABILITY STATEMENT}

The original contributions presented in the study are included in the article/Supplementary Material, further inquiries can be directed to the corresponding author.

\section{AUTHOR CONTRIBUTIONS}

SW, NR and LN designed the study and wrote the original draft of the manuscript. SW, AK, LN and NR acquired funding. AK, AA, SW, LSc and MF participated in the field investigation and collected sample material. KS supervised pollen preparation. NR and MP performed pollen analysis and interpretation. LN and LSy performed chironomid analysis and interpretation. OP performed diatom analysis and interpretation. TK performed mammal bone analysis and interpretation. JW and MF supported overall proxy data interpretation. All authors contributed in writing and editing the manuscript.

\section{FUNDING}

This work has been supported by the by the Russian Foundation of Basic Research (RFBR grant No. 18-05-60221 to AK) and the Deutsche Forschungsgemeinschaft (DFG grants No. WE4390/7-1 to SW and NA760/8-1 to LN). NR worked in the frame of project NIR IAET SB RAS No. 0264-2019-0010. MF was supported by the NUNATARYUK project that has received funding from the European Union's Horizon 2020 research and innovation program under grant agreement No. 773421.

\section{ACKNOWLEDGMENTS}

We thank our colleagues from the Hydrobaza Tiksi for help with fieldwork in 2018 that was conducted in the framework of the joint Russian-German expeditions LENA 2018 supported by the Samoylov Research Station. Sarah Olischläger (AWI Potsdam) is acknowledged for pollen preparation.

\section{SUPPLEMENTARY MATERIAL}

The Supplementary Material for this article can be found online at: https://www.frontiersin.org/articles/10.3389/feart.2021.681511/ full\#supplementary-material 


\section{REFERENCES}

Anderson, P. M., and V. Lozhkin, A. (2001). The Stage 3 Interstadial Complex (Karginskii/middle Wisconsinan Interval) of Beringia: Variations in Paleoenvironments and Implications for Paleoclimatic Interpretations. Quat. Sci. Rev. 20, 93-125. doi:10.1016/S0277-3791(00)00129-3

Andreev, A. A., Schirrmeister, L., Siegert, Ch., Bobrov, A. A., Demske, D., Seiffert, M., et al. (2002). Paleoenvironmental changes in northeastern Siberia during the Upper Quaternary e evidence from pollen records of the Bykovsky Peninsula. Polarforschung 70, 13-25. doi:10.2312/polarforschung.70.13

Andreev, A. A., Schirrmeister, L., Tarasov, P. E., Ganopolski, A., Brovkin, V., Siegert, C., et al. (2011). Vegetation and Climate History in the Laptev Sea Region (Arctic Siberia) during Late Quaternary Inferred from Pollen Records. Quat. Sci. Rev. 30, 2182-2199. doi:10.1016/j.quascirev.2010.12.026

Are, F., and Reimnitz, E. (2000). An Overview of the Lena River Delta Setting: Geology, Tectonics, Geomorphology, and Hydrology. J. Coastal Res. 16 (4), 1083-1093. doi:10.2307/4300125

Barinova, S. S., Medvedeva, L. A., and Anisimova, O. V. (2006). Bioraznoobrazie Vodoroslei-Indikatorov Okruzhayushchei Sredy (Biological Diversity of Algae-Environmental Indicators). Pilies Studio: Tel Aviv.

Battarbee, R. W. (1986). "Diatom Analysis," in Handbook of Holocene Paleoecology and Palaeohydrology. Editor B. E. Berglund (New York: Wiley), 527-570.

Beug, H.-J. (2004). Leitfaden der Pollenbestimmung für Mitteleuropa und angrenzende Gebiete. München: Verlag Friedrich Pfeil.

Biskaborn, B. K., Nazarova, L., Pestryakova, L. A., Syrykh, L., Funck, K., Meyer, H., et al. (2019). Spatial Distribution of Environmental Indicators in Surface Sediments of Lake Bolshoe Toko, Yakutia, Russia. Biogeosciences 16, 4023-4049. doi:10.5194/bg-2019-14610.5194/bg-16-4023-2019

Bobrov, A. A., Andreev, A. A., Schirrmeister, L., and Siegert, C. (2004). Testate Amoebae (Protozoa: Testacealobosea and Testaceafilosea) as Bioindicators in the Late Quaternary Deposits of the Bykovsky Peninsula, Laptev Sea, Russia. Palaeogeogr. Palaeoclimatol. Palaeoecol. 209, 165-181. doi:10.1016/ j.palaeo.2004.02.012

Boike, J., Nitzbon, J., Anders, K., Grigoriev, M., Bolshiyanov, D., Langer, M., et al. (2019). A 16-year Record (2002-2017) of Permafrost, Active-Layer, and Meteorological Conditions at the Samoylov Island Arctic Permafrost Research Site, Lena River delta, Northern Siberia: an Opportunity to Validate Remote-Sensing Data and Land Surface, Snow, and Permafrost Models. Earth Syst. Sci. Data 11 (1), 261-299. doi:10.5194/essd-11-261-2019

Brooks, S. J., and Birks, H. J. B. (2000). Chironomid-inferred Late-Glacial and Early-Holocene Mean July Air Temperatures for Kråkenes Lake, Western Norway. J. Paleolimnology 23, 77-89. doi:10.1023/A:1008044211484

Brooks, S. J., Langdon, P. G., and Heiri, O. (2007). Using and Identifying Chironomid Larvae in palaeoecologyQRA Technical Guide No. 10. London, UK: Quaternary Research Association.

Brosius, L. S., Anthony, K. M. W., Treat, C. C., Lenz, J., Jones, M. C., Bret-Harte, M. S., et al. (2021). Spatiotemporal Patterns of Northern lake Formation since the Last Glacial Maximum. Quat. Sci. Rev. 253, 106773. doi:10.1016/ j.quascirev.2020.106773

Chen, J., Günther, F., Grosse, G., Liu, L., and Lin, H. (2018). Sentinel-1 InSAR Measurements of Elevation Changes over Yedoma Uplands on Sobo-Sise Island, Lena Delta. Remote Sensing 10 (7), 1152. doi:10.3390/rs10071152

Fægri, K., and Iversen, J. (1989). Textbook of Pollen Analysis. fourth edition. Chichester: John Wiley \& Sons.

Fedorova, I., Chetverova, A., Bolshiyanov, D., Makarov, A., Boike, J., Heim, B., et al. (2015). Lena Delta Hydrology and Geochemistry: Long-Term Hydrological Data and Recent Field Observations. Biogeosciences 12 (2), 345-363. doi:10.5194/bg-12-345-2015

Francis, D. R., Wolfe, A. P., Walker, I. R., and Miller, G. H. (2006). Interglacial and Holocene Temperature Reconstructions Based on Midge Remains in Sediments of Two Lakes from Baffin Island, Nunavut, Arctic Canada. Palaeogeogr. Palaeoclimatol. Palaeoecol. 236, 107-124. doi:10.1016/ j.palaeo.2006.01.005

Fuchs, M., Grosse, G., Strauss, J., Günther, F., Grigoriev, M., Maximov, G. M., et al. (2018). Carbon and Nitrogen Pools in Thermokarst-Affected Permafrost Landscapes in Arctic Siberia. Biogeosciences 15 (3), 953-971. doi:10.5194/bg15-953-2018
Fuchs, M., Nitze, I., Strauss, J., Günther, F., Wetterich, S., Kizyakov, A., et al. (2020). Rapid Fluvio-thermal Erosion of a Yedoma Permafrost Cliff in the Lena River Delta. Front. Earth Sci. 8, 336. doi:10.3389/feart.2020.00336

Grigoriev, M. N. (1988). The Role of Cryomorphogenesis in the Evolution of the Lena River Estuary Relief in the Holocene (Роль КриоморфоГенеза В Лволюции Рельефа Устьевой Области Р. Лена В Голоцене). Studies of Permafrost Strata and Cryogenic Phenomena (Исследования Мерзлыч Толщ И КриоГенныч Явлений). Yakutsk: Institute of Permafrost of the Siberian Branch of the USSR Academy of Sciences, Yakutsk, 22-28.(in Russian).

Grimm, E. C. (2004). TGView 2.0.2 (Software). Springfield, Illinois: Illinois State Museum.

Grosse, G., Robinson, J. E., Bryant, R., Taylor, M. D., Harper, W., DeMasi, A., et al. (2013). Distribution of Late Pleistocene Ice-Rich Syngenetic Permafrost of the Yedoma Suite in East and central Siberia, Russia. U.S. Geological Survey Open File Report, Open-File Report 2013-1078, 37.

Günther, F., Grosse, G., Maximov, G., Veremeeva, A., Haghshenas Haghighi, M., and Kizyakov, A. (2018). Repeat LiDAR for Tracking Extensive Thaw Subsidence on Yedoma Uplands. Book Of Abstracts, International Symposium 20 Years Of Lena-Delta Expeditions, 17-19 October 2018. St. Petersburg, RussiaSt. Petersburg: Arctic and Antarctic Research Institute, $22-24$.

Guthrie, R. D. (1990). Frozen Fauna of the Mammoth Steppe: The story of Blue Babe. Chicago and London: The University of Chicago Press, 323.

Heiri, O., and Lotter, A. F. (2001). Effect of Low Count Sums on Quantitative Environmental Reconstructions: an Example Using Subfossil Chironomids. J. Paleolimnology 26, 343-350. doi:10.1023/A:1017568913302

Hill, M. O. (1973). Diversity and Evenness: a Unifying Notation and its Consequences. Ecology 54 (2), 427-432. doi:10.2307/1934352

Hoff, U., Biskaborn, B. K., Dirksen, V. G., Dirksen, O., Kuhn, G., Meyer, H., et al. (2015). Holocene Environment of Central Kamchatka, Russia: Implications from a Multi-Proxy Record of Two-Yurts Lake. Glob. Planet. Change 134, 101-117. doi:10.1016/j.gloplacha.2015.07.011

Hopkins, D. M. (1959). Cenozoic History of the Bering Land Bridge: The Seaway between the Pacific and Arctic Basins Has Often Been a Land Route between Siberia and Alaska. Science 129 (3362), 1519-1528. doi:10.1126/ science.129.3362.1519

IBCAO grid (2021). Online source. Available at: https://www.gebco.net/data_and_ products/gridded_bathymetry_data/arctic_ocean/((Accessed January 11, 2021).

Juggins, S. (2007). C2 Version 1.5 User Guide. Software for Ecological and Paleoecological Data Analysis and Visualization. Newcastle: Newcastle University.

Kanevskiy, M., Shur, Y., Fortier, D., Jorgenson, M. T., and Stephani, E. (2011). Cryostratigraphy of Late Pleistocene Syngenetic Permafrost (Yedoma) in Northern Alaska, Itkillik River Exposure. Quat. Res. 75, 584-596. doi:10.1016/j.yqres.2010.12.003

Katasonov, E. M. (2009). Litologiya Merzlykh Chetvertichnykh Otlozhenii (Kriolotologiya) Yanskoi Primorkoi Nizmenosti (Lithology of Frozen Quaternary Deposits (Cryolithology) of the Yana lowland). Moscow, Russia: Production and Research Institute for Engineering Surveys and Construction (ШНИИИС) Publishers, 175 (in Russian).

Khazin, L. B., Khazina, I. V., Kuzmina, O. B., Ayunov, D. E., Golikov, N. A., and Tsibizov, L. V. (2019). A Borehole Record of Late Quaternary Permafrost on Kurungnakh Island (Lena Delta, Northeastern Siberia): Reconstruction of Deposition Environments. Russ. Geology. Geophys. 60 (7), 768-780. doi:10.1134/S004451341911010210.15372/RGG2019045

Kienast, F., Schirrmeister, L., Siegert, C., and Tarasov, P. (2005). Palaeobotanical Evidence for Warm Summers in the East Siberian Arctic during the Last Cold Stage. Quat. Res. 63, 283-300. doi:10.1134/S004451341911010210.1016/ j.yqres.2005.01.003

Kienast, F., Wetterich, S., Kuzmina, S., Schirrmeister, L., Andreev, A. A., Tarasov, P., et al. (2011). Paleontological Records Indicate the Occurrence of Open Woodlands in a Dry Inland Climate at the Present-Day Arctic Coast in Western Beringia during the Last Interglacial. Quat. Sci. Rev. 30 (17-18), 2134-2159. doi:10.1016/j.quascirev.2010.11.024

Krammer, K., and Lange-Bertalot, H. (1986). Bacillariophyceae. Teil 1: Naviculaceae. Süßwasserflora von Mitteleuropa. Stuttgart: Gustav Fischer Verlag. 
Krammer, K., and Lange-Bertalot, H. (1988). Bacillariophyceae. Teil 2: Bacillariaceae, Epitemiaceae, Surirellaceae. Süßwasserflora von Mitteleuropa. Stuttgart: Gustav Fischer Verlag.

Krammer, K., and Lange-Bertalot, H. (1991a). Bacillariophyceae. Teil 3: Centrales, Fragilariaceae, Eunotiaceae. Süßwasserflora von Mitteleuropa. Stuttgart: Gustav Fischer Verlag.

Krammer, K., and Lange-Bertalot, H. (1991b). Bacillariophyceae. Teil 4: Achnanthaceae, Kritische Ergänzungen zu Navicula (Lineolatae) und Gomphonema. Gesamtliteraturverzeichnis. Süßwasserflora von Mitteleuropa. Stuttgart: Gustav Fischer Verlag.

Kunitsky, V. V., Syromyatnikov, I. I., Schirrmeister, L., Skachov, Y. B., Grosse, G., Wetterich, S., et al. (2013). L'distye porody i termodenudatsiya v raione poselka Batagay, Yanskoe ploskogor'e, Vostochnaya Sibir' (Ice-rich permafrost and thermal denudation in the Batagay area, Yana Upland, East Siberia). Kriosfera Zemli (Earth's Cryosphere) 17 (1), 56-58.

Kuznetsova, T. V., Tumskoy, V. E., Schirrmeister, L., and Wetterich, S. (2019). Paleozoological Characteristics of Late Neopleistocene - Holocene Deposits of the Bykovsky Peninsula (Палеозоологическая храктеристика ПоздненеоПлейстоцен-олоценовых Отложений Быковского Полуострова (Северная Якутия) Zoolog. J. (ЗоолоГический журнал) 98 (11), 1268-1290. doi:10.1134/S0044513419110102

Laing, T. E., Rühland, K. M., and Smol, J. P. (1999). Past Environmental and Climatic Changes Related to Tree-Line Shifts Inferred from Fossil Diatoms from a lake Near the Lena River Delta, Siberia. The Holocene 9, 547-557. doi:10.1191/095968399675614733

Larocque, I. (2001). How many Chironomid Head Capsules Are Enough? A Statistical Approach to Determine Sample Size for Palaeoclimatic Reconstructions. Palaeogeogr. Palaeoclimatol. Palaeoecol. 172, 133-142. doi:10.1016/S0031-0182(01)00278-4

Margold, M., Jansen, J. D., Codilean, A. T., Preusser, F., Gurinov, A. L., Fujioka, T., et al. (2018). Repeated Megafloods from Glacial Lake Vitim, Siberia, to the Arctic Ocean over the Past 60,000 Years. Quat. Sci. Rev. 187, 41-61. doi:10.1016/j.quascirev.2018.03.005

Martin-Jézéquell, V., and Lopez, P. J. (2003). "Silicon - a central Metabolite for Diatom Growth and Morphogenesis,". Silicon Biomineralization. Progress in Molecular and Subcellular Biology. Editor W. E. G. Müller (Berlin, Heidelberg: Springer), 33, 99-124. doi:10.1007/978-3-642-55486-5_4

Moller Pillot, H. K. M. (2009). Chironomidae Larvae. Biology and Ecology of the Chironomini. Zeist, Netherlands: KNNV Publishing, 270.

Moller Pillot, H. K. M. (2013). Chironomidae Larvae. Biology and Ecology of the Aquatic Orthocladiinae. Zeist, Netherlands: KNNV Publishing, 312.

Morgenstern, A., Ulrich, M., Günther, F., Roessler, S., Fedorova, I. V., Rudaya, N. A., et al. (2013). Evolution of Thermokarst in East Siberian Ice-Rich Permafrost: A Case Study. Geomorphology 201, 363-379. doi:10.1016/j.geomorph.2013.07.011

Müller, S., Tarasov, P. E., Andreev, A. A., and Diekmann, B. (2009). Late Glacial to Holocene Environments in the Present-Day Coldest Region of the Northern Hemisphere Inferred from a Pollen Record of Lake Billyakh, Verkhoyansk Mts, NE Siberia. Clim. Past 5, 73-84. doi:10.5194/cp-5-73-2009

Nazarova, L. B., Pestryakova, L. A., Ushnitskaya, L. A., and Hubberten, H.-W. (2008). Chironomids (Diptera: Chironomidae) in Lakes of Central Yakutia and Their Indicative Potential for Paleoclimatic Research. Contemp. Probl. Ecol. 1, 335-345. doi:10.1134/S1995425508030089

Nazarova, L., Herzschuh, U., Wetterich, S., Kumke, T., and Pestryakova, L. (2011). Chironomid-based Inference Models for Estimating Mean July Air Temperature and Water Depth from Lakes in Yakutia, Northeastern Russia. J. Paleolimnol 45, 57-71. doi:10.1007/s10933-010-9479-4

Nazarova, L., Lüpfert, H., Subetto, D., Pestryakova, L., and Diekmann, B. (2013). Holocene Climate Conditions in central Yakutia (Eastern Siberia) Inferred from Sediment Composition and Fossil Chironomids of Lake Temje. Quat. Int. 290291, 264-274. doi:10.1016/j.quaint.2012.11.006

Nazarova, L., Self, A. E., Brooks, S. J., van Hardenbroek, M., Herzschuh, U., and Diekmann, B. (2015). Northern Russian Chironomid-Based Modern Summer Temperature Data Set and Inference Models. Glob. Planet. Change 134, 10-25. doi:10.1016/j.gloplacha.2014.11.015

Nazarova, L., Bleibtreu, A., Hoff, U., Dirksen, V., and Diekmann, B. (2017a). Changes in Temperature and Water Depth of a Small mountain lake during the Past 3000 Years in Central Kamchatka Reflected by a Chironomid Record. Quat. Int. 447, 46-58. doi:10.1016/j.quaint.2016.10.008
Nazarova, L. B., Self, A. E., Brooks, S. J., Solovieva, N., Syrykh, L. S., and Dauvalter, V. A. (2017b). Chironomid Fauna of the Lakes from the Pechora River basin (East of European Part of Russian Arctic): Ecology and Reconstruction of Recent Ecological Changes in the Region. Contemp. Probl. Ecol. 10, 350-362. doi:10.1134/S1995425517040059

Nazarova, L., Grebennikova, T. A., Razjigaeva, N. G., Ganzey, L. A., Belyanina, N. I., Arslanov, K. A., et al. (2017c). Reconstruction of Holocene Environmental Changes in Southern Kurils (North-Western Pacific) Based on Palaeolake Sediment Proxies from Shikotan Island. Glob. Planet. Change 159, 25-36. doi:10.1016/j.gloplacha.2017.10.005

Nazarova, L., Syrykh, L. S., Frolova, R. J. L. A., Ibragimova, A. G., Grekov, I. M., Subetto, D. A., et al. (2020). Palaeoecological and Palaeoclimatic Conditions on the Karelian Isthmus (Northwestern Russia) during the Holocene. Quat. Res. 95, 65-83. doi:10.1017/qua.2019.88

Neretina, A. N., Gololobova, M. A., Neplyukhina, A. A., Zharov, A. A., Rogers, C. D., Horne, D. J., et al. (2020). Crustacean Remains from the Yuka mammoth Raise Questions about Non-analogue Freshwater Communities in the Beringian Region during the Pleistocene. Sci. Rep. 10, 859. doi:10.1038/ s41598-020-57604-8

New, M., Lister, D., Hulme, M., and Makin, I. (2002). A High-Resolution Data Set of Surface Climate over Global Land Areas. Clim. Res. 21, 1-25. doi:10.3354/ cr021001

Opel, T., Meyer, H., Wetterich, S., Laepple, T., Dereviagin, A., and Murton, J. (2018). Ice Wedges as Archives of winter Paleoclimate: A Review. Permafrost and Periglac Process 29, 199-209. doi:10.1002/ppp.1980

Opel, T., Murton, J. B., Wetterich, S., Meyer, H., Ashastina, K., Günther, F., et al. (2019). Past Climate and Continentality Inferred from Ice Wedges at Batagay Megaslump in the Northern Hemisphere's Most continental Region, Yana Highlands, interior Yakutia. Clim. Past 15, 1443-1461. doi:10.5194/cp-151443-2019

Overpeck, J. T., Webb, T., and Prentice, I. C. (1985). Quantitative Interpretation of Fossil Pollen Spectra: Dissimilarity Coefficients and the Method of Modern Analogs. Quat. Res. 23, 87-108. doi:10.1016/ 0033-5894(85)90074-2

Palagushkina, O. V., Nazarova, L. B., Wetterich, S., and Schirrmeister, L. (2012). Diatoms of Modern Bottom Sediments in Siberian Arctic. Contemp. Probl. Ecol. 5 (4), 413-422. doi:10.1134/S1995425512040105

Palagushkina, O. V., Wetterich, S., Schirrmeister, L., and Nazarova, L. B. (2017). Modern and Fossil Diatom Assemblages from Bol'shoy Lyakhovsky Island (New Siberian Archipelago, Arctic Siberia). Contemp. Probl. Ecol. 10, 380-394. doi:10.1134/S1995425517040060

Péwé, T. L. (1955). Origin of the upland silt Near Fairbanks, Alaska. Geol. Soc. America Bull. 66, 699-724. doi:10.1130/0016-7606(1955)66[699:ootusn] 2.0.co;2

Pestryakova, L. A., Herzschuh, U., Gorodnichev, R., and Wetterich, S. (2018). The Sensitivity of Diatom Taxa from Yakutian Lakes (north-eastern Siberia) to Electrical Conductivity and Other Environmental Variables. Polar Res. 37, 1485625. doi:10.1080/17518369.2018.1485625

Pitulko, V., Pavlova, E., and Nikolskiy, P. (2017). Revising the Archaeological Record of the Upper Pleistocene Arctic Siberia: Human Dispersal and Adaptations in MIS 3 and 2. Quat. Sci. Rev. 165, 127-148. doi:10.1016/ j.quascirev.2017.04.004

Plikk, A., Engels, S., Luoto, T. P., Nazarova, L., Salonen, J. S., and Helmens, K. F. (2019). Chironomid-based temperature reconstruction for the Eemian Interglacial (MIS 5e) at Sokli, northeast Finland. J. Paleolimnol 61, 355-371. doi:10.1007/s10933-018-00064-y

Proshkina-Lavrenko, A. I. (1974). Diatoms Of the USSR - Fossils And Modern (Диатомовые Водоросли СССР - ИскоШаемые И СовременныеЏ. Leningrad: Nauka, 403.(in Russian).

Quinlan, R., and Smol, J. P. (2001). Chironomid-based Inference Models for Estimating End-Of-Summer Hypolimnetic Oxygen from South-central Ontario Shield Lakes. Freshw. Biol. 46, 1529-1551. doi:10.1046/j.13652427.2001.00763.x

Raschke, E. A., and Savelieva, L. A. (2017). Subrecent Spore-Pollen Spectra and Modern Vegetation from the Lena River Delta, Russian Arctic. Contemp. Probl. Ecol. 10 (4), 395-410. doi:10.1134/S1995425517040084

Reimer, P. J., Bard, E., Bayliss, A., Beck, J. W., Blackwell, P. G., Ramsey, C. B., et al. (2013). IntCal13 and Marine13 Radiocarbon Age Calibration Curves 0- 
50,000 Years Cal BP. Radiocarbon 55, 1869-1887. doi:10.2458/ azu_js_rc.55.16947

Reimer, P. J., Austin, W. E. N., Bard, E., Bayliss, A., Blackwell, P. G., Bronk Ramsey, C., et al. (2020). The IntCal20 Northern Hemisphere Radiocarbon Age Calibration Curve (0-55 Cal kBP). Radiocarbon 62 (4), 725-757. doi:10.1017/RDC.2020.41

Rogers, D. C., Zharov, A. A., Neretina, A. N., Kuzmina, S. A., and Kotov, A. A. (2021). A Review of Recently Discovered Remains of the Pleistocene Branchiopods (Anostraca, Notostraca) from NE Siberia and Arctic Canada. Water 13, 280. doi:10.3390/w13030280

Rothe, M., Kleeberg, A., and Hupfer, M. (2016). The Occurrence, Identification and Environmental Relevance of Vivianite in Waterlogged Soils and Aquatic Sediments. Earth-Science Rev. 158, 51-64. doi:10.1016/j.earscirev.2016.04.008

Schirrmeister, L., Siegert, C., Siegert, C., Kuznetsova, T., Kuzmina, S., Andreev, A., et al. (2002a). Paleoenvironmental and Paleoclimatic Records from Permafrost Deposits in the Arctic Region of Northern Siberia. Quat. Int. 89, 97-118. doi:10.1016/S1040-6182(01)00083-0

Schirrmeister, L., Siegert, C., Kunitzky, V. V., Grootes, P. M., and Erlenkeuser, H. (2002b). Late Quaternary Ice-Rich Permafrost Sequences as a Paleoenvironmental Archive for the Laptev Sea Region in Northern Siberia. Int. J. Earth Sci. 91, 154-167. doi:10.1007/s005310100205

Schirrmeister, L., Grosse, G., Schwamborn, G., Andreev, A. A., Meyer, H., Kunitsky, V. V., et al. (2003). Late Quaternary History of the Accumulation Plain North of the Chekanovsky Ridge (Lena Delta, Russia): A Multidisciplinary Approach. Polar Geogr. 27, 277-319. doi:10.1080/789610225

Schirrmeister, L., Kunitsky, V., Grosse, G., Wetterich, S., Meyer, H., Schwamborn, G., et al. (2011a). Sedimentary Characteristics and Origin of the Late Pleistocene Ice Complex on north-east Siberian Arctic Coastal Lowlands and Islands - A Review. Quat. Int. 241, 3-25. doi:10.1016/j.quaint.2010.04.004

Schirrmeister, L., Grosse, G., Schnelle, M., Fuchs, M., Krbetschek, M., Ulrich, M., et al. (2011b). Late Quaternary Paleoenvironmental Records from the Western Lena Delta, Arctic Siberia. Palaeogeogr. Palaeoclimatol. Palaeoecol. 299, 175-196. doi:10.1016/j.palaeo.2010.10.045

Schirrmeister, L., Froese, D., Tumskoy, V., Grosse, G., and Wetterich, S. (2013). "PERMAFROST and PERIGLACIAL FEATURES | Yedoma: Late Pleistocene Ice-Rich Syngenetic Permafrost of Beringia," in The Encyclopedia of Quaternary Science. Editor S. A. Elias (Amsterdam: Elsevier), 542-552. doi:10.1016/B978-0444-53643-3.00106-0

Schirrmeister, L., Meyer, H., Andreev, A., Wetterich, S., Kienast, F., Bobrov, A., et al. (2016). Late Quaternary Paleoenvironmental Records from the Chatanika River valley Near Fairbanks (Alaska). Quat. Sci. Rev. 147, 259-278. doi:10.1016/ j.quascirev.2016.02.009

Schirrmeister, L., Schwamborn, G., Overduin, P. P., Strauss, J., Fuchs, M. C., Grigoriev, M., et al. (2017). Yedoma Ice Complex of the Buor Khaya Peninsula (Southern Laptev Sea). Biogeosciences 14, 1261-1283. doi:10.5194/bg-14-12612017

Sher, A. V., Kuzmina, S. A., Kuznetsova, T. V., and Sulerzhitsky, L. D. (2005). New Insights into the Weichselian Environment and Climate of the East Siberian Arctic, Derived from Fossil Insects, Plants, and Mammals. Quat. Sci. Rev. 24, 533-569. doi:10.1016/j.quascirev.2004.09.007

Soloviev, P. A. (1959). Kriolitozona Severnoy Chasti Leno-Amginskogo Mezhdurech'ya (The Permafrost of the Northern Part of the Lena-Amga Interfluve). Moscow: Academy of Science Press, 142.(in Russian).

Solovieva, N., Klimaschewski, A., Self, A. E., Jones, V. J., Andrén, E., Andreev, A. A., et al. (2015). The Holocene Environmental History of a Small Coastal lake on the north-eastern Kamchatka Peninsula. Glob. Planet. Change 134, 55-66. doi:10.1016/j.gloplacha.2015.06.010

Stockmarr, J. (1971). Tablets with Spores Used in Absolute Pollen Analysis. Pollen et Spores 13, 615-621.

Syrykh, L. S., Nazarova, L. B., Herzschuh, U., Subetto, D. A., and Grekov, I. M. (2017). Reconstruction of Palaeoecological and Palaeoclimatic Conditions of the Holocene in the South of the Taimyr According to an Analysis of lake Sediments. Contemp. Probl. Ecol. 10, 363-369. doi:10.1134/ S1995425517040114

van Geel, B. (2001). "Non-pollen Palynomorphs,". Terrestrial Algal and Siliceous Indicators, Tracking Environmental Changes Using lake Sediments. Editors J. P. Smol, H. J. B. Birks, and W.M. Last (Dordrecht: Kluwer Academic Press), 3, 99-119.
Wasser, S. P., Kondratyeva, N. V., Masyuk, N. P., Palamar'-Mordvintseva, G. M., Vetrova, Z. I., Kordyum, E. L., et al. (1989). Algae - Guide (Водоросли Справочник. Kiev: Naukova Dumka, 608.(in Russian).

Wetterich, S., Schirrmeister, L., and Pietrzeniuk, E. (2005). Freshwater Ostracodes in Quaternary Permafrost Deposits in the Siberian Arctic. J. Paleolimnol 34, 363-376. doi:10.1007/s10933-005-5801-y

Wetterich, S., Kuzmina, S., Andreev, A. A., Kienast, F., Meyer, H., Schirrmeister, L., et al. (2008a). Palaeoenvironmental Dynamics Inferred from Late Quaternary Permafrost Deposits on Kurungnakh Island, Lena Delta, Northeast Siberia, Russia. Quat. Sci. Rev. 27 (15), 1523-1540. doi:10.1016/j.quascirev.2008.04.007

Wetterich, S., Schirrmeister, L., Meyer, H., Viehberg, F. A., and Mackensen, A. (2008b). Arctic Freshwater Ostracods from Modern Periglacial Environments in the Lena River Delta (Siberian Arctic, Russia): Geochemical Applications for Palaeoenvironmental Reconstructions. J. Paleolimnol 39, 427-449. doi:10.1007/ s10933-007-9122-1

Wetterich, S., Schirrmeister, L., Andreev, A. A., Pudenz, M., Plessen, B., Meyer, H., et al. (2009). Eemian and Late Glacial/Holocene Palaeoenvironmental Records from Permafrost Sequences at the Dmitry Laptev Strait (NE Siberia, Russia). Palaeogeogr. Palaeoclimatol. Palaeoecol. 279, 73-95. doi:10.1016/j.palaeo.2009.05.002

Wetterich, S., Rudaya, N., Tumskoy, V., Andreev, A. A., Opel, T., Schirrmeister, L., et al. (2011). Last Glacial Maximum Records in Permafrost of the East Siberian Arctic. Quat. Sci. Rev. 30, 3139-3151. doi:10.1016/j.quascirev.2011.07.020

Wetterich, S., Tumskoy, V., Rudaya, N., Andreev, A. A., Opel, T., Meyer, H., et al. (2014). Ice Complex Formation in Arctic East Siberia during the MIS3 Interstadial. Quat. Sci. Rev. 84, 39-55. doi:10.1016/j.quascirev.2013.11.009

Wetterich, S., Schirrmeister, L., Nazarova, L., Palagushkina, O., Bobrov, A., Pogosyan, L., et al. (2018). Holocene Thermokarst and Pingo Development in the Kolyma Lowland (NE Siberia). Permafrost and Periglac Process 29 (3), 182-198. doi:10.1002/ppp.1979

Wetterich, S., Rudaya, N., Kuznetsov, V., Maksimov, F., Opel, T., Meyer, H., et al. (2019a). Ice Complex Formation on Bol'shoy Lyakhovsky Island (New Siberian Archipelago, East Siberian Arctic) since about 200 Ka. Quat. Res. 92 (2), 530-548. doi:10.1017/qua.2019.6

Wetterich, S., Kizyakov, A., Fritz, M., Aksenov, A., Schirrmeister, L., and Opel, T. (2019b). Permafrost Research on Sobo-Sise Island (Lena Delta). Rep. Polar Mar. Res. 734, 102-113. doi:10.2312/BzPM_0734_2019

Wetterich, S., Kizyakov, A., Fritz, M., Wolter, J., Mollenhauer, G., Meyer, H., et al. (2020). The Cryostratigraphy of the Yedoma Cliff of Sobo-Sise Island (Lena delta) Reveals Permafrost Dynamics in the central Laptev Sea Coastal Region during the Last 52 Kyr. The Cryosphere 14, 4525-4551. doi:10.5194/tc-14-4525-2020

Wetterich, S., Meyer, H., Fritz, M., Mollenhauer, G., Rethemeyer, J., Kizyakov, A., et al. (2021). Northeast Siberian Permafrost Ice-Wedge Stable Isotopes Depict Pronounced Last Glacial Maximum Winter Cooling. Geophys. Res. Lett. 48, e2020GL092087. doi:10.1029/2020GL092087

Wiederholm, T. (1983). Chironomidae of the Holarctic Region. Keys and Diagnoses. Part 1. Larvae. Entomologica Scand. Suppl. 19, 1-457.

World Topo Base (2021). Online Source. Available at: https://www.arcgis.com/home/ item.html?id=3a75a3eeld1040838f382cbefce99125 Accessed. January 11, 2021.

Zabelina, M. M., Kiselev, I. A., Proshkina-Lavrenko, A. I., and Sheshukova, V. S. (1951). Diatoms. In: Opredelitel' Presnovodnykh Vodoroslei SSSR (Guide for Identification of Freshwater Algae in Soviet Union). Moscow: Sovetskaya Nauka.(in Russian).

Conflict of Interest: The authors declare that the research was conducted in the absence of any commercial or financial relationships that could be construed as a potential conflict of interest.

The reviewer NS declared a past co-authorship with several of the authors LN, NR, LSy, and OP.

Copyright $\odot 2021$ Wetterich, Rudaya, Nazarova, Syrykh, Pavlova, Palagushkina, Kizyakov, Wolter, Kuznetsova, Aksenov, Stoof-Leichsenring, Schirrmeister and Fritz. This is an open-access article distributed under the terms of the Creative Commons Attribution License (CC BY). The use, distribution or reproduction in other forums is permitted, provided the original author(s) and the copyright owner(s) are credited and that the original publication in this journal is cited, in accordance with accepted academic practice. No use, distribution or reproduction is permitted which does not comply with these terms. 